$1-2003$

\title{
The Relationship Between Teacher Implementation of America's Choice and Student Learning in Plainfield, New Jersey
}

Jonathan A. Supovitz

University of Pennsylvania, JONS@GSE.UPENN.EDU

Henry May

Follow this and additional works at: https://repository.upenn.edu/cpre_researchreports

Part of the Curriculum and Instruction Commons, Educational Administration and Supervision Commons, Educational Assessment, Evaluation, and Research Commons, Educational Methods Commons, and the Teacher Education and Professional Development Commons

\section{Recommended Citation}

Supovitz, Jonathan A. and May, Henry. (2003). The Relationship Between Teacher Implementation of America's Choice and Student Learning in Plainfield, New Jersey. CPRE Research Reports.

Retrieved from https://repository.upenn.edu/cpre_researchreports/32

View on the CPRE website.

This paper is posted at ScholarlyCommons. https://repository.upenn.edu/cpre_researchreports/32

For more information, please contact repository@pobox.upenn.edu. 


\title{
The Relationship Between Teacher Implementation of America's Choice and Student Learning in Plainfield, New Jersey
}

\author{
Abstract \\ Rarely in educational research do we have access to data that allow us to empirically explore the \\ relationships between the practices of individual teachers and the learning of their students. This report is \\ one of those exceptional cases. In this report, we use data from Plainfield, New Jersey in which individual \\ teachers' survey responses about America's Choice were linked to the test gains of the students who \\ were taught by those teachers. By working closely with district administrators, we were able to link \\ individual survey responses to the district's student achievement databases while retaining the \\ confidentiality of both teachers and students. \\ The result is an uncommon piece of evidence that empirically links teachers' implementation of America's \\ Choice to student learning. The pattern from these results seems clear and persistent: the students of \\ teachers who more deeply implemented the America's Choice model, particularly the writers workshop \\ component of the design, learned more than did the students of teachers who had lower levels of \\ implementation. Even after statistically controlling for the background characteristics of teachers and \\ students and for students' prior test performance, teachers' implementation of America's Choice was \\ associated with significantly higher learning gains for students. \\ Disciplines \\ Curriculum and Instruction | Educational Administration and Supervision | Educational Assessment, \\ Evaluation, and Research | Educational Methods | Teacher Education and Professional Development

\section{Comments} \\ View on the CPRE website.
}




\title{
The Relationship Between Teacher Implementation of America's Choice and Student Learning in Plainfield, New Jersey
}

\author{
Jonathan A. Supovitz \\ Henry May \\ Consortium for Policy Research in Education \\ University of Pennsylvania
}

January 2003

(c) Copyright 2003 by the Consortium for Policy Research in Education 



\section{Contents}

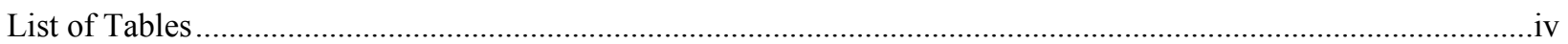

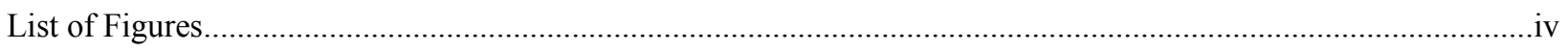

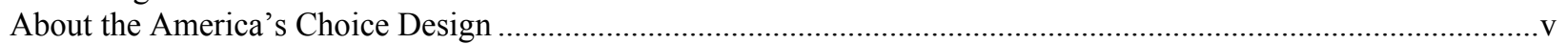

About CPRE's Evaluation of the America's Choice Design .......................................................................... vii

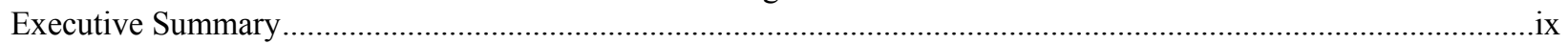

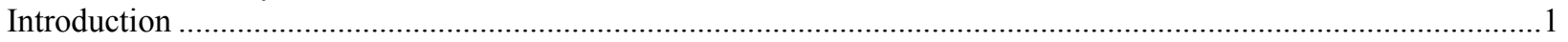

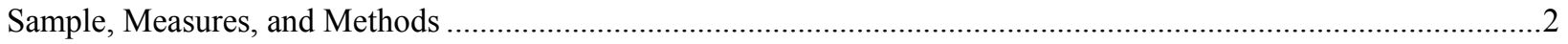

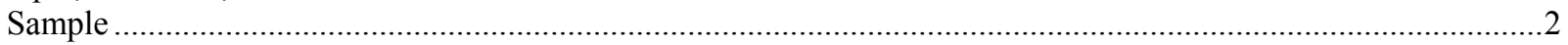

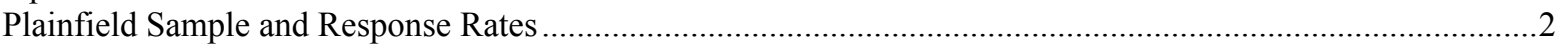

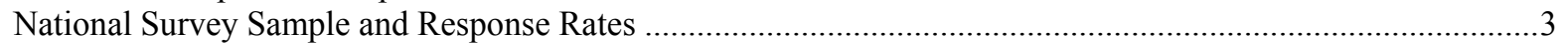

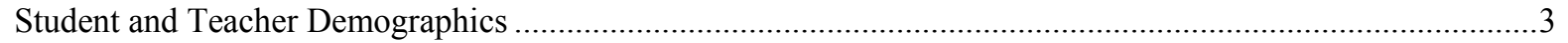

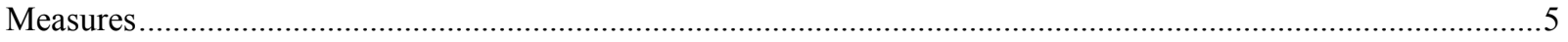

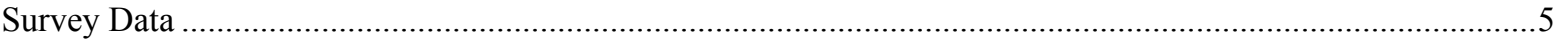

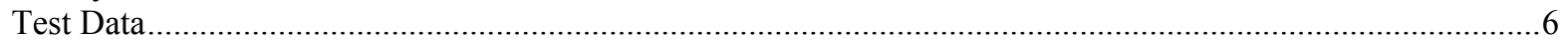

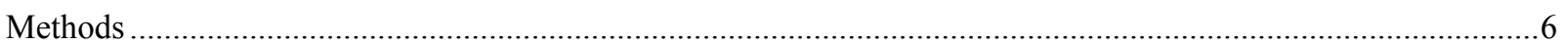

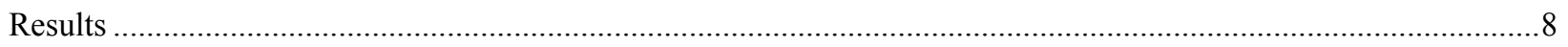

Impact on Teachers' Overall Implementation of America's Choice on Student Learning ..................................9

Predictors of Teachers' Overall Implementation of America's Choice .....................................................10

Impact of Implementation of Writers Workshop on Student Learning …................................................12

Predictors of Teachers' Preparation to Teach Writers Workshop ..........................................................15

Impact of Implementation of Readers Workshop on Student Learning.........................................................17

Predictors of Teachers' Preparation to Teach Readers Workshop............................................................... 19

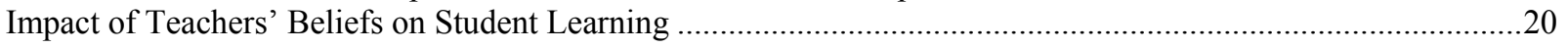

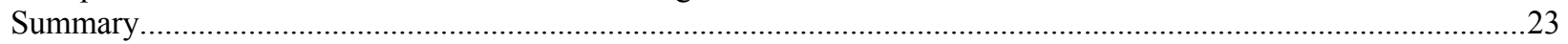

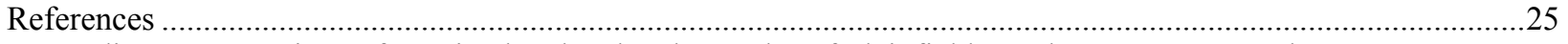

Appendix A. Comparison of Retained and Deleted Samples of Plainfield Teachers on Four Teacher

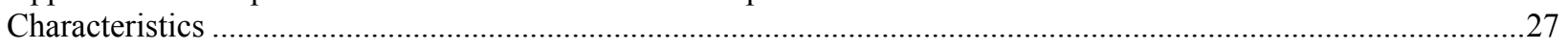

Appendix B. Comparison of Retained and Deleted Samples of Students on Eight Characteristics .........................28

Appendix C. Survey Scales ...............................................................................................................29

Appendix D. Regression Coefficients from the Full Model (including control variables) Predicting Achievement

Gains from Overall Implementation of America's Choice ....................................................................

Appendix E. Regression Coefficients from the Full Model (including control variables) Predicting Achievement

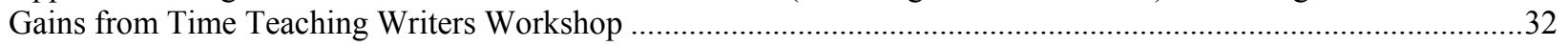

Appendix F. Regression Coefficients from the Full Model (including control variables) Predicting Achievement Gains from Preparation to Teach Writers Workshop.....................................................................................33

Appendix G. Regression Coefficients from the Full Model (including control variables) Predicting Achievement

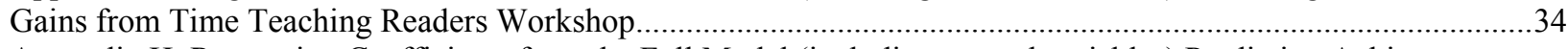

Appendix H. Regression Coefficients from the Full Model (including control variables) Predicting Achievement

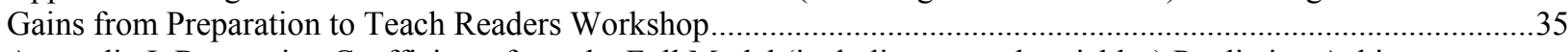

Appendix I. Regression Coefficients from the Full Model (including control variables) Predicting Achievement

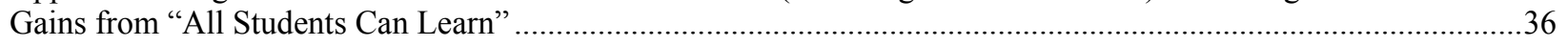

Appendix J. Regression Coefficients from the Full Model (including control variables) Predicting Achievement

Gains from "Same Standards Should Apply to All Students" 


\section{List of Tables}

Table 1. Demographic Characteristics of America's Choice Teachers in Plainfield and a National Sample ...............4

Table 2. Demographic Characteristics of Students in Plainfield in Grades 2-6...................................................4

Table 3. Percent of Primary and Upper Elementary Teachers Reporting Use of Different Components of America's

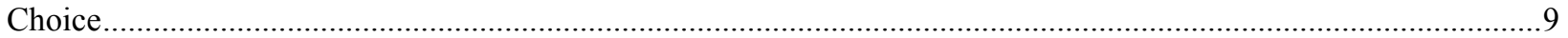

Table 4. Results of Model Predicting Student Achievement Gains by the Extent of Teacher Overall Implementation

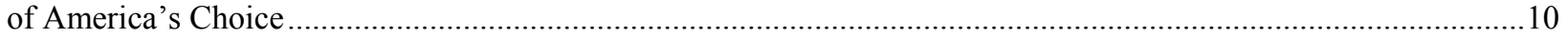

Table 5. Teacher and School Characteristics Predicting Overall America's Choice Implementation.......................12

Table 6. Results of Model Predicting Student Achievement Gains by the Extent of Teacher Implementation of

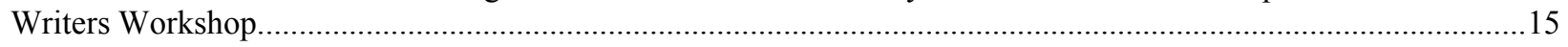

Table 7. Teacher and School Characteristics Predicting Teacher Preparation to Teach Writers Workshop ..............16

Table 8. Results of Model Predicting Student Achievement Gains by the Extent of Teacher Implementation of

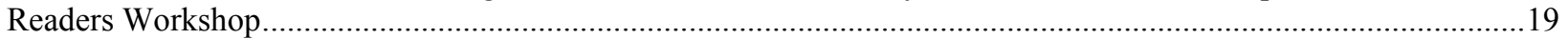

Table 9. Teacher and School Characteristics Predicting Teacher Preparation to Teach Readers Workshop .............21

Table 10. Results of Model Predicting Student Achievement Gains by Teacher Beliefs ....................................23

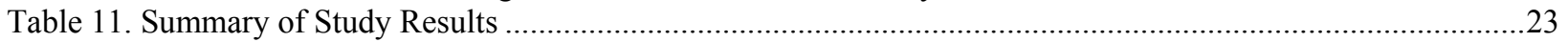

\section{List of Figures}

Figure 1. Relationship Between Overall Teacher Implementation of America's Choice and Student Learning

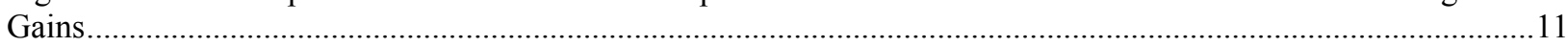

Figure 2. Time Plainfield Teachers Reported Teaching Writers Workshop.....................................................13

Figure 3. Plainfield Teachers' Preparation to Teach Writers Workshop ..............................................................14

Figure 4. Relationships Between Teachers' Preparation to Teach Writers Workshop and Student Learning Gains...15

Figure 5. Time Plainfield Teachers Reported Teaching Readers Workshop ....................................................17

Figure 6. Plainfield Teachers' Preparation to Teach Readers Workshop .......................................................18

Figure 7. Relationships Between Teachers' Preparation to Teach Readers Workshop and Student Learning Gains..20

Figure 8. Plainfield Teachers' Belief that all Students Can Learn ................................................................22

Figure 9. Plainfield Teachers' Belief that the Same Standards Should be Applied to all Students ..........................22 


\section{About the America's Choice Design}

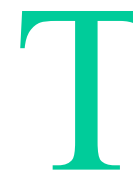

he America's Choice School Design is a K-12 comprehensive school reform model designed by the National Center on Education and the Economy (NCEE). America's Choice focuses on raising academic achievement by providing a rigorous standards-based curriculum and safety net for all students. The goal of America's Choice is to make sure that all but the most severely handicapped students reach an internationally benchmarked standard of achievement in English/language arts and mathematics by the time they graduate.

America's Choice does not offer schools a script or a paint-by-numbers approach to reformed instruction. America's Choice recognizes that the pace of change will vary from school to school. Furthermore, the model does not have a rigid three-year implementation schedule.

Rather, the core of the design contains a set of principles about the purpose of schooling and how schools should operate as well as a set of tools for building a program based on those principles. These essential principles and tools include:

- High expectations for student performance that specify what students should know and be able to do at certain educational junctures. These standards are explicitly expressed through the New Standards Performance Standards that provide a common set of expectations for students and teachers.

- An initial focus on literacy that features elements of phonics, oral language, shared books, guided and independent reading, daily writing, and independent writing.
- A common core curriculum that is aligned with the standards. Through the America's Choice literacy workshops, Core Assignments, and Foundations of Advanced Mathematics, school life is organized around a core curriculum.

- Standards-based assessments, including the New Standards Reference Examination, that are aligned with the standards and the core curriculum, and that provide detailed feedback to teachers and students about student skill levels in relation to the standards.

- A distributed school leadership structure, led by the school's principal, that coordinates implementation, analyzes results and sets performance targets, implements safety-net programs to provide time for students to receive additional instruction, ensures the necessary resources, and aligns schedules and other school activities with implementation of the design.

- Safety nets that are structured into the school day and school year and that provide students with extensive support and multiple opportunities to achieve the standards.

- A commitment to teacher professionalism that enables teachers to function as full professionals by providing ongoing, on-site professional development and support that is aligned with the standards and in which content and pedagogy are intimately connected.

In order to become an America's Choice school, over $80 \%$ of a school's faculty must indicate their commitment to the America's Choice design and agree to implement the program over a period of three years. Each school must assign personnel as coaches to lead the implementation of the design, and a parent/community outreach coordinator who ensures that students get needed support services. 


\section{About CPRE's Evaluation of the America's Choice Design}

I n 1998, the Consortium for Policy Research in Education (CPRE) at the University of Pennsylvania was contracted by NCEE to conduct the external evaluation of the America's Choice School Design. Each year CPRE designs and conducts a series of targeted studies on the implementation and impacts of the America's Choice design. This report is one of this year's evaluations on the relationship between teacher implementation of America's Choice and student learning in Plainfield. The publication of this report coincides with the release of three separate studies by CPRE on the impact of America's Choice in a number of districts across the nation using a variety of quantitative and analytic approaches. Those impact analyses and a standalone piece on classroom observations conducted in Cohort 4 schools can be viewed as separate pieces or as complements to the information presented in this report. Another recent CPRE publication is a widely distributed report entitled, Instructional Leadership in a Standards-based Reform, a companion piece to both the impact reports and this report.

The purpose of CPRE's evaluation is to provide formative feedback to NCEE and America's Choice schools about emerging trends in the implementation of the design, and to seek evidence of the impacts of the design using accepted high standards of evaluation design and analysis methodologies.

CPRE's evaluation of America's Choice is guided by three overarching evaluation questions. First, is America's Choice being carried out in the manner envisioned - that is, how are teachers and school administrators understanding and implementing the many facets of the reform design? Second, as a result of teachers' implementation of America's Choice, are their instructional practices changing in ways that would improve student learning? Third, to what degree can improvements in student achievement be attributed to the design? Within this framework, annual evaluation studies target specific aspects of the America's Choice design for more in-depth investigation.

To address these questions, the CPRE evaluation team gathers a broad array of qualitative and quantitative data to develop a rich and valid snapshot of the implementation process over time and to capture the impacts of the design on students and teachers. Our data sources include:

- Surveys of teachers and administrators in America's Choice schools nationwide.

- Site visits to schools across the United States to observe classroom instruction, examine implementation artifacts, and interview teachers, students, and school administrators.

- Telephone interviews with NCEE staff, school faculty members, and school and district administrators.

- Document reviews.

- Observations of national, regional, and school-level professional development.

- Collection of student performance measures, including state and local tests, the New Standards Reference Examination, and more authentic samples of student work products.

After data collection, CPRE research team members analyze the data using appropriate qualitative and quantitative research techniques in order to identify patterns of intended and unintended consequences and to detect effects of the design on students, teachers, and schools. The results are reported in a series of thematic evaluation reports that are released each year. 
The following evaluation reports are also currently available from CPRE. Print copies are available at no cost by emailing cpre@gse.upenn.edu, or by calling 215-573-0700. Copies can also be downloaded at www.cpre.org.

- Impact of America's Choice on Student Performance in Duval County, Florida (Jonathan Supovitz, Brooke Snyder Taylor, and Henry May, October 2002)

- Implementation of the America's Choice Literacy Workshops (Jonathan Supovitz, Susan Poglinco, and Amy Bach, April 2002)

- Instructional Leadership in a Standardsbased Reform (Jonathan Supovitz and Susan Poglinco, December 2001)

- Moving Mountains: Successes and Challenges of the America's Choice Comprehensive School Reform Design (Jonathan Supovitz, Susan Poglinco, and Brooke Snyder, March 2001)

- America's Choice Comprehensive School Reform Design: First-year Implementation Evaluation Summary (Thomas Corcoran, Margaret Hoppe, Theresa Luhm, and Jonathan Supovitz, February 2000) 


\section{Executive Summary}

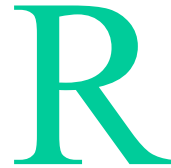

arely in educational research do we have access to data that allow us to empirically explore the relationships between the practices of individual teachers and the learning of their students. This report is one of those exceptional cases. In this report, we use data from Plainfield, New Jersey in which individual teachers' survey responses about America's Choice were linked to the test gains of the students who were taught by those teachers. By working closely with district administrators, we were able to link individual survey responses to the district's student achievement databases while retaining the confidentiality of both teachers and students.

The result is an uncommon piece of evidence that empirically links teachers' implementation of America's Choice to student learning. The pattern from these results seems clear and persistent: the students of teachers who more deeply implemented the America's Choice model, particularly the writers workshop component of the design, learned more than did the students of teachers who had lower levels of implementation. Even after statistically controlling for the background characteristics of teachers and students and for students' prior test performance, teachers' implementation of America's Choice was associated with significantly higher learning gains for students. More specifically, the major findings from this study are:

- On a spring 2001 survey conducted by CPRE, teachers were asked about different aspects of their implementation of America's Choice. Ten aspects were aggregated into a scale with which we represented teachers' overall implementation of America's Choice. In the upper elementary grades (grades 4-6), the students of teachers with higher levels of implementation of America's Choice gained significantly more on state tests than did students of low-implementing teachers, even after controlling for teacher and student background characteristics. This difference in student performance was equivalent to a $1 \%$ increase in the number of correct responses for every unit of increased implementation. For example, all other things being equal, the students whose teachers reported implementing all 10 elements of America's Choice performed $5 \%$ higher than did students of teachers who reported implementing 5 of the design's 10 elements.

- The essential aspects of the America's Choice literacy model are readers and writers workshops. We tested the relationship between two aspects of these workshops and student test performance gains. We found no relationship between the time that teachers reported implementing either readers or writers workshop and gains in student learning. There were, however, strong and consistent statistical relationships between instructors' preparation to teach readers and writers workshops and student test performance gains. These gains ranged from a $2.3 \%$ to $3.2 \%$ increase in the number of correct test answers for every unit of increasing preparation that teachers reported (on the four-point preparation scale). Thus, for example, all other things being equal, students of teachers who reported feeling very well prepared to teach the workshops had between $9.2 \%$ to $12.8 \%$ more correct answers than did students of teachers who reported feeling not adequately prepared to teach the workshops.

- Teachers whose beliefs were consistent with the philosophy underlying America's Choice tended to report deeper levels of implementation of the various components of America's Choice. Both in Plainfield and nationally, teachers who answered survey items consistent with a belief that all students can learn were inclined to report deeper implementation of America's Choice. Similarly, teachers who believed that the same standards should be applied to all students also reported deeper implementation of America's Choice. Yet, 
beliefs alone were not enough to boost student learning. Teacher beliefs were not statistically associated with gains in student test performance. Rather, it appears, teacher beliefs facilitated the implementation that produced students' learning gains.

Finally, the reader should understand the context of the implementation of America's Choice in Plainfield, a small high-poverty district of 13 schools in central New Jersey, and the high level of support provided by the district. The district's leadership has taken an active interest in instructional improvement and embraced standards-based reform in general, and America's Choice in particular, throughout the district. This may be a contributing factor to the effectiveness of America's Choice in Plainfield. 


\section{Introduction}

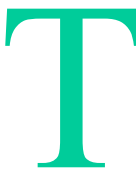

his study is designed to explore the relationship between teachers' implementation of different aspects of America's Choice and the learning gains of their students. The study uses teacher and student data collected in Plainfield, New Jersey as well as teacher data collected from instructors in America's Choice schools across the nation. We had two purposes for conducting this study. First, we sought to explore the relationships between teacher implementation of various components of America's Choice and student learning. Second, we intended to examine whether and which teacher characteristics were associated with teachers' implementation of the different components of America's Choice.

Teachers' implementation of different components of America's Choice was measured through a survey administered by CPRE in the spring of 2001 to all teachers in America's Choice schools across the nation, including those in Plainfield. Student learning in Plainfield was measured by the growth in student test performance from the spring of 2000 to the spring of 2001. Thanks to the cooperation of teachers and district leaders in Plainfield, CPRE was allowed to link teacher surveys to student test performance. The purpose of linking student performance data to teachers was not to identify successful or struggling individual teachers, but rather to explore large-scale patterns of the relationship between instructional practices and student learning gains.

Plainfield is a K-12 urban school district that serves approximately 7,500 students in 10 elementary schools, 2 middle schools, and 1 high school. Plainfield is located in central New Jersey, about 30 miles from New York City. The students in the district are predominantly African American (71\%) and Hispanic (28\%). Sixty-five percent of the students receive either free or reduced-price lunch.

On New Jersey's complex, seven-category index of district poverty, Plainfield is rated in the second highest poverty category. As one of the poorest districts in the state, a so-called "Abbott district," Plainfield receives additional state funding, and each of its schools is required to adopt a school reform model. In 1999, six of the district's elementary schools and one middle school adopted America's Choice, joining the second national cohort of schools using the design. The following year, two additional elementary schools and one middle school joined the third cohort of America's Choice. The Plainfield schools chose America's Choice because they had already been implementing district-wide literacy reforms that were consistent with the America's Choice literacy design.

The district's leaders have also wholly embraced high standards for students in general and America's Choice in particular. District support includes supportive policies, a strong investment in professional development for teachers and teacher leaders, and a passionate commitment to standards-based reform. This enthusiasm is perhaps best embodied in the district's mission statement which reads: "The Plainfield Public Schools, in partnership with its community, shall do whatever it takes for every student to achieve high academic standards - no alibis, no excuses, no exceptions" (Plainfield Public Schools, n.d.).

Following this introduction, we describe the data that comprised these analyses, how they were organized into a variety of measures, and the methods used to analyze the data. Next, we describe the results. First, we examine the relationship between teachers' overall implementation of America's Choice and associated gains in student learning. Second, we explore the relationship between teachers' implementation of writers workshop, the main

\footnotetext{
${ }^{1}$ In Abbott vs. Burke, the New Jersey Supreme Court ruled that the education provided to the state's urban school children was both inadequate and unconstitutional and ordered the state to assure that such children receive an adequate education through implementation of a broad set of programs and reforms. The Court explicitly limited the programs and reforms to districts identified as poorer urban districts or special-needs districts. These districts have come to be known as Abbott districts.
} 
writing instruction component of the America's Choice design, and gains in student learning. Here we explore two aspects of teachers' implementation of writers workshop - the time that teachers implemented writers workshop and their feelings of preparation to implement writers workshop - and gains in student learning. Third, we conduct similar analyses for readers workshop, the major reading instruction component of America's Choice. Fourth, we examine the relationship between teachers' beliefs about student learning, as reported by survey responses, and gains in student learning. Throughout our discussion of the results, in those cases where implementation of America's Choice was associated with student learning, we explore what teacher background characteristics, classroom characteristics, and teacher attitudinal beliefs were related to implementation. We conclude the report with a summary of the results.

\section{Sample, Measures, and Methods}

This section outlines the data, measures, and methods used in this study. First, we describe the sample of teachers and students whose survey results and test data formed the bases for this study, including the response rates associated with data collection and simple descriptive statistics of the teachers and students. Second, we describe how we organized the survey responses into data on a variety of scales that measured different dimensions of teacher implementation of America's Choice. We then detail the statistical methods we used to estimate the relationships between teachers' implementation of America's Choice and students' test score gains after controlling for the background characteristics of students and teachers.

\section{Sample}

In this section, we summarize the sample and demographics of teachers and students in Plainfield, and a comparative sample of America's Choice teachers across the nation.

\section{Plainfield Sample and Response Rates}

For these analyses, we used data from 114 general elementary, English/language arts, reading, or writing teachers, and 1,572 students from first through sixth grades in 10 schools during the 2000-2001 school year. Student demographic and test score data for the 19992000 and 2000-2001 school years were extracted from district databases. The number of students in each grade was fairly evenly distributed. Teachers in all of the America's Choice schools in the district were asked to complete a survey containing items relevant to the implementation of the America's Choice design in their classroom.

Plainfield administered an achievement test to every first through sixth grader in reading/language arts in 2000-2001. In order to measure individual student learning gains from one year to the next, test scores are needed for both the current year and the prior year. The fact that Plainfield did not administer any test to seventh graders restricted the study to an analysis of test data for students who were in grades 2 through 6 during the current school year (2000-2001). Based on district records, there were 2,187 students in grades 2 through 6 in Plainfield in 2000-2001. Of these students, we have two years of valid test data for 1,898 students, or $87 \%$ of the target population.

According to Plainfield district records, there were 429 teachers in these 10 schools in the 2000-2001 school year. CPRE sent surveys to each of these teachers in the spring of 2001 and received completed surveys from 381 teachers (89\%). Of these, 186 teachers indicated that they were general elementary, English/language arts, reading, or writing teachers in at least one grade from first to sixth grade.

Due to missing data for both students and teachers, merging the teacher data with the student data resulted in additional loss of data at both levels. Students whose teachers did not complete a survey were dropped from the analyses, as were teachers without any valid 
student data. Of the 2,187 students in the target population, 1,572 remained in our sample, for a participation rate of $72 \%$. Of the 186

English/language arts teachers for whom we had survey data, 114 , or $61 \%$, were linked to students with reading/language arts data.

Potential bias resulting from missing data in Plainfield was explored by comparing the characteristics of students and teachers retained in the final sample to those of the students and teachers deleted from the final data set (i.e., students without teacher data, and teachers without student data). This was done via chisquare tests of independence for categorical variables and t-tests of mean differences for continuous variables. The $\mathrm{p}$-values for these collections of tests were adjusted for multiple comparisons using the Bonferroni method.

Those teachers retained in the sample were compared with those deleted on four dimensions: gender, ethnicity, certification, and experience. There were no statistical differences between the two groups in any of these dimensions. Students who were retained in the sample were compared to those removed on eight characteristics (grade, ethnicity, gender, special education status, lunch assistance, mobility, and 2000 and 2001 achievement). Of these, students were similar in terms of grade level, gender, ethnicity, special education status, and mobility. The students removed from the sample were more likely to be on free or reduced-price lunch (66\% compared to $54 \%$ ), and had a lower average score correct on the New Jersey state reading test in 2000 (575 compared to 586) and lower percent score in 2001 (40\% compared to $42 \%$ ). The full statistics of these comparison tests are shown in Appendices A and B.

\section{National Survey Sample and Response Rates}

Additional analyses were conducted comparing the responses of Plainfield teachers to a national sample of America's Choice teachers to explore similarities and differences between Plainfield teachers and other America's Choice teachers across the United States. Our national sample of teachers came from CPRE's population survey of America's Choice teachers conducted in the spring of 2001. Of the 200 schools from across the nation that were participating in America's Choice in the spring of 2001, 188 returned surveys, for a school response rate of $94 \%$. Within those schools returning surveys, response rates ranged from $22 \%$ to $100 \%$, with an average response rate of $68 \%$.

To compare the Plainfield responses to a similar national sample, we extracted from the national data a random sample of teachers that matched the Plainfield sample in terms of the proportion of teachers beginning implementation of America's Choice at the same time as those in Plainfield. Most of the Plainfield teachers began implementation during the second wave (Cohort 2), while the remainder began implementation during the third wave (Cohort 3). All of the Cohort 2 teachers from the national sample were selected $(n=785)$, along with a random sample of Cohort 3 teachers $(n=392)$, so that the total proportion of teachers from each cohort in the national sample matched the proportions of the Plainfield data. Our final sample of national America's Choice teachers included 1,177 teachers from 136 schools.

\section{Student and Teacher Demographics}

Table 1 shows the demographics for both the teachers in Plainfield in 2001 and for a similar national sample of America's Choice teachers in 2001. The Plainfield teachers are decomposed into primary grade (2-3) teachers and upper elementary grade (4-6) teachers because the 


\section{Table 1. Demographic Characteristics of America's Choice Teachers} in Plainfield and a National Sample

\begin{tabular}{lccc}
\hline & $\begin{array}{c}\text { Plainfield } \\
\text { Primary } \\
\text { Grade } \\
\text { (grades 2-3) } \\
\text { Teachers } \\
(\mathrm{n}=62)\end{array}$ & $\begin{array}{c}\text { Plainfield } \\
\text { Upper Elementary } \\
\text { Grade } \\
\text { (grades 4-6) } \\
\text { Teachers } \\
(\mathrm{n}=52)\end{array}$ & $\begin{array}{c}\text { National } \\
\text { America's Choice } \\
\text { Sample } \\
(\mathrm{n}=1,177)\end{array}$ \\
Teacher Characteristic & 91 & 73 & 82 \\
\hline Percent female & 33 & 51 & 21 \\
Percent African American & 63 & 43 & 62 \\
Percent White & 98 & 92 & 90 \\
Subject-certified vs. non-subject-certified & & & 12 \\
teachers & 11 & 12 & $(10)$ \\
Average years of experience (with & $(10)$ & $110)$ & $1-45$ \\
standard deviation) & $1-42$ & 63 & 38 \\
Minimum/maximum years of experience & 52 & 19 & 23 \\
Percent class teachers & 20 & $(4)$ & $(4)$ \\
Average class size (with standard & $(4)$ & $4-25$ & $5-60$ \\
deviation) & $5-25$ & & \\
Minimum/maximum class size & & & \\
\hline
\end{tabular}

impact of America's Choice implementation on student test performance gains was estimated separately for two grade ranges.

Within Plainfield, a larger proportion of the primary grade teachers were White females than either the upper elementary grades or the national sample of teachers from similar cohorts. In all groups, over $90 \%$ of the teachers were certified in their subjects and all groups were similarly experienced. A higher percentage of Plainfield teachers reported being class teachers (those teaching the same groups of students over multiple years) than did the national sample in the same cohorts. Class sizes in Plainfield were slightly smaller than they were nationally (20 compared to 23 students, on average).

The demographic characteristics for students in Plainfield are shown in Table 2, decomposed into primary grade students (grades 2-3) and upper elementary grade students (grades 4-6). Overall, the two groups were similar, with about half the students being female, and over $80 \%$ African American. Almost $60 \%$ of the students in the primary grades received lunch assistance, while roughly $40 \%$ of the students in the upper elementary grades received lunch assistance.

\section{Table 2. Demographic Characteristics of Students in Plainfield in Grades 2-6}

\begin{tabular}{lcc}
\hline Student Characteristic & $\begin{array}{c}\text { Primary } \\
\text { Grades } \\
\text { (grades 2-3) } \\
(\mathrm{n}=750)\end{array}$ & $\begin{array}{c}\text { Upper Elementary } \\
\text { Grades } \\
\text { (grades 4-6) } \\
(\mathrm{n}=822)\end{array}$ \\
\hline Percent female & 50 & 51 \\
Percent African American & 82 & 82 \\
Percent Hispanic & 16 & 18 \\
Percent receiving free/reduced-price lunch & 58 & 41 \\
\hline
\end{tabular}




\section{Measures}

Here, we discuss the measures and methods used in our analyses. The measures consist of both the survey data - with which we measured teachers' demographics, implementation, and beliefsand test data. The methods describe the analytical techniques that we used to explore the relationship between the survey and test results.

\section{Survey Data}

To develop predictor variables for our models, we used both individual items and scales in which teachers' responses to individual survey items are aggregated. Here, we briefly describe each of these predictor variables and what they represent. Appendix C lists the individual items that were used to develop scales as well as their reliabilities.

Several composite scales were constructed from items included in the teacher survey. To maximize the validity of these scales, Factor Analysis was used to identify survey items that stemmed from common constructs. For this analysis, the Plainfield teacher data was supplemented with additional teacher survey data from other sites, resulting in a total sample of 5,066 teachers. Communalities were estimated iteratively, and the method of factor rotation was Varimax. Clusters of items with common response categories were analyzed separately, and the number of factors to extract was determined through Parallel Analysis (Horn, 1965). After defining the factors, unit weighting of items was used to generate factor scores for each teacher. These scales, and the items comprising them, are described in more detail in the section about predictor variables.

America's Choice Overall Implementation. This 10 -item scale represented an overall picture of a teacher's implementation of the classroom components of America's Choice, including use of the 25 Book Campaign, the New Standards Performance Standards and Reference Exam, book logs, and rubrics.
Time Teaching Readers Workshop. This single item asked teachers how long they had been teaching the America's Choice readers workshop. Potential responses were on a fivepoint scale consisting of never, about a quarter of a school year, about half a school year, almost one full school year, and more than one school year.

Readers Workshop Preparation. This single item asked teachers how prepared they felt to teach the America's Choice readers workshop. Potential responses were on a four-point scale consisting of not adequately prepared, somewhat prepared, fairly well prepared, and very well prepared.

Time Teaching Writers Workshop. This single item asked teachers how long they had been teaching the America's Choice writers workshop. Responses were constrained to a fivepoint scale consisting of never, about a quarter of a school year, about half a school year, almost one full school year, and more than one school year.

Writers Workshop Preparation. This single item asked teachers how prepared they felt to teach the America's Choice writers workshop. Potential responses were on a four-point scale consisting of not adequately prepared, somewhat prepared, fairly well prepared, and very well prepared.

Belief that All Students Can Learn. This sevenitem scale asked teachers for their agreement with a series of statements designed to gauge teachers' beliefs about student learning. Items included questions about whether teachers believed most students were capable of learning the material that teachers were expected to teach, whether student success was based more on ability than effort, and whether students could work together without close supervision. Potential responses were on a four-point scale consisting of strongly disagree, somewhat disagree, somewhat agree, and strongly agree.

Belief that Same Standards Should Apply to All Students. This four-item scale asked teachers for their agreement with a series of statements 
intended to assess their belief that all students should meet high standards of performance. Items included questions about whether teachers used the same criteria to judge the quality of student work, and whether special education students and English language learners should be held to the same standards as regular education students. Potential responses were on a four-point scale consisting of strongly disagree, somewhat disagree, somewhat agree, and strongly agree.

\section{Test Data}

Test scores for the 1999-2000 school year are from the New Jersey Goals Performance Assessment (NJGOALS). The NJGOALS test contained 10 open-ended questions that asked students to read a passage or prompt and write a response. Each student's responses are scored by at least two trained readers using scoring rubrics. The results of NJGOALS are reported both as scale scores and percentile ranks. The scale scores from the NJGOALS test are used in this analysis. Test scores from the 2000-2001 school year are from the Elementary School Proficiency Assessment (ESPA), administered in the fourth grade, and the New Jersey PASS performance assessment (NJPASS), administered in grades 1 , 2, 3, 5, and 6. Both the ESPA and NJPASS contain both multiple-choice and open-response items and provide a combined English/language arts score. The ESPA is reported by proficiencylevel scores and scale scores. The ESPA scale scores are used in this analysis. The NJPASS is reported by proficiency-level scores and percent correct scores. The percent correct scores were found to be remarkably normally distributed (as determined by visual inspection of normalquantile plots), and were used in this analysis. All test scores were standardized to a mean of zero and a standard deviation of one. This removes any artifactual influences of differences in test score scaling, and allows the use of the NJGOALS as a prior achievement control variable when predicting performance on the NJPASS and ESPA.

\section{Methods}

Our analyses followed a particular pattern. First, we examined the relationship of an aspect of teachers' implementation of America's Choice to the learning of their students. Second, if a relationship existed, we explored what teacher and/or classroom characteristics are related to that aspect of implementation. Here we describe the methods used in each of these types of analyses.

\section{Relating America's Choice implementation data} to student learning. Given that groups of students are assigned to individual teachers, our data has an inherently nested structure (i.e., students within classrooms). Furthermore, two students from the same classroom are likely to be more similar than two students selected randomly from the population. As a result of these characteristics, traditional statistical models are inappropriate for these data. Fortunately, an alternative method known as "hierarchical" or "multilevel" modeling is specifically designed to deal with these issues (Raudenbush \& Bryk, 2002). Hierarchical linear modeling (HLM) is also able to produce effect estimates that are corrected for multiple control variables. In this analysis, we controlled for differences in student background (i.e., gender, ethnicity, free/reduced-price lunch status, mobility) and for differences in teacher background characteristics (i.e., gender, ethnicity, and years of experience).

All of the variables used in these analyses had some degree of missing data. Missing achievement data for either year necessarily resulted in deletion of that observation. Missing data for other variables was handled by including indicator variables (one for each original variable) in the models that are equal to zero if data is present and equal to one if data is missing for a given variable. The missing value for the original variable was then recoded to zero (although any number can be used). In effect, observations with missing data for a particular variable do not contribute to that variable's effect estimation; however, they continue to contribute to the calculation of the 
effects of all other variables. This technique is often referred to as a "dummy variable correction" for missing data and is commonly used in education research (for an example, see Goldhaber \& Brewer, 2000). The actual missing data rates were below $15 \%$ for all variables except one: teacher race had a missing data rate of $25 \%$.

Each America's Choice implementation variable was analyzed with a separate model, although each model included the same seven control variables. This was done because the implementation items all represented specific aspects of one main construct (i.e., implementation in general). Including more than one implementation variable in a model would have produced estimates that represented the effect of one implementation variable above and beyond the effects of other implementation variables in the model. Alternatively, the separate analysis of each variable produces effect estimates that show the total effect of each implementation variable without removing the effect of the general level of implementation.
As such, each effect estimate must be considered separately as an estimate of the relationship between teachers' implementation of America's Choice and student learning. Although their relative sizes can be compared, they cannot be added together for any purpose.

To maximize the ability to detect relationships if they were actually present (i.e., maximize statistical power), all students and teachers were pooled together for each analysis. As previously noted, the fourth graders in 2000-2001 took a different test than the rest of the sample. To adjust for the possibility of different relationships between the NJGOALS/ESPA and the NJGOALS/NJPASS test scores, an additional parameter was added to the model to allow the correlation between the NJGOALS and the ESPA to differ from the correlation between the NJGOALS and the NJPASS test scores. ${ }^{2}$ The equations for the final models had the following general form:

$\begin{aligned} \text { Level 1: READING2001 } & \beta_{0 \mathrm{j}} \\ \text { (Student) } & +\beta_{1} \text { READING2000 }+\beta_{2} \text { READING2000x ESPA } \\ & +\beta_{3} \text { MALE } \\ & +\beta_{4} \text { WHITE } \\ & +\beta_{5} \text { HISPANIC } \\ & +\beta_{6} \text { OTHER } \\ & +\beta_{7} \text { FRE } / \text { REDUCED-PRICE LUNCH STATUS } \\ & +\beta_{8} \text { MOBILITY } \\ & +\beta_{9} \text { MISSING } \\ & +\beta_{10} \text { MISSINDER }_{\text {RACE }} \\ & +\beta_{11} \text { MISSING }_{\text {LUNCH STATUS }} \\ & +\beta_{12} \text { MISSING }_{\text {MOBILITY }} \\ & +r_{\mathrm{ij}}\end{aligned}$

${ }^{2}$ The ESPA factor in this model is coded 1 if the score for 2001 is from the ESPA and 0 otherwise. A main effect of the ESPA factor is not necessary because all test scores are standardized to a mean of 0 . Therefore, the main effect of ESPA is 0 , and does not require estimation or inclusion in the model. 


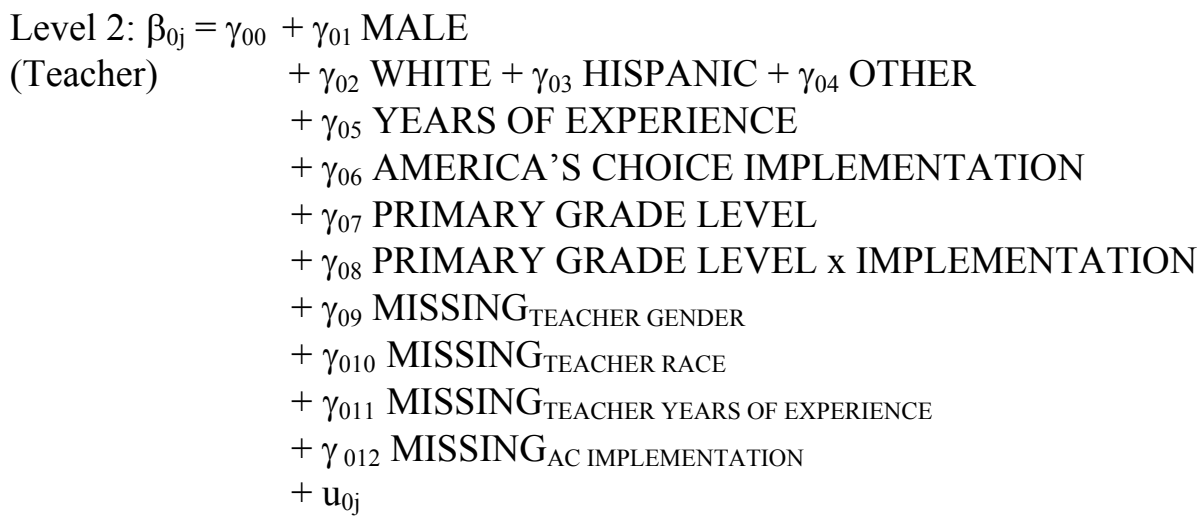

This type of HLM model is called a "random intercept model." While each classroom has a random intercept, all of the slope parameters in the model are considered "fixed" and assumed not to vary across classrooms. The parameter $\beta_{0 \mathrm{j}}$ in both levels of the model is the Empirical Bayes $^{3}$ estimate of the expected performance gain for students in classroom $\mathrm{j}$, after controlling for student background variables. The ESPA adjustment parameter is $\beta_{2}$. The reference category (the omitted category to which all other categories are compared) for both student and teacher race is African American. The parameter $\gamma_{06}$ shows the estimated number of test score standard deviations associated with a one-unit change in the level of implementation of America's Choice after controlling for student and teacher background characteristics. The parameters $r_{i j}$ and $u_{0 j}$ are random error terms associated with students and teachers respectively. Each model was estimated using PROC MIXED in SAS 8.2.

\section{Relating teacher characteristics to} implementation of America's Choice. In order to explore the factors which predict varying levels of teachers' implementation of America's Choice, additional models were estimated with the America's Choice implementation variables as the dependent variables. These models were ordinary least squares (OLS) regression models

\footnotetext{
${ }^{3}$ See chapter 3 in Raudenbush and Bryk (2002) for a discussion of Empirical Bayes estimates in HLM models.
}

where a single teacher-level variable was used to predict an indicator of implementation. No other control variables were added to these models. Just as before, the separate analysis of predictor variables prohibits the aggregation of effect estimates for any purpose.

The OLS models exploring relationships between predictor variables and implementation variables were estimated using both the survey data from Plainfield teachers and the survey data from the national sample of teachers.

\section{Results}

In this section, we report the results of the series of analyses that explored the relationships between different aspects of teachers' implementation of America's Choice and student learning, as measured by gains in student standardized test performance. First, we examine the impact of teachers' overall implementation of America's Choice on student learning. Second, we explore the relationship between teachers' implementation of writers workshop and student learning. Third, we investigate the relationship between teachers' implementation of readers workshop and student learning. Fourth, we probe relationships between teacher beliefs and student learning. The results are arrayed in a consistent pattern. We examine the relationship between teachers' implementation of a particular aspect of America's Choice and student learning outcomes, and, in those cases where we discover a statistically significant relationship, we proceed to explore what teacher 
and classroom characteristics predict that particular aspect of implementation. For example, we explore the relationship between overall America's Choice implementation and student learning. After detecting a relationship (for upper elementary students), we then examine what teacher background and attitudinal characteristics and classroom characteristics are associated with teachers' overall implementation of America's Choice. In cases where we do not find a relationship between implementation and student learning, we do not bother exploring the predictors of that particular aspect of implementation.

\section{Impact on Teachers" Overall Implementation of America's Choice on Student Learning}

Our scale of teachers' overall implementation of America's Choice consisted of 10 survey items which we used as a collective measure of the degree to which Plainfield teachers were implementing the key components of the America's Choice design. Examining the distribution of responses on each of these items, shown in Table 3, reveals several interesting things. First, 6 of the 10 items that were included in this scale had very little variation; the overwhelming majority of teachers (more than $90 \%$ ) in both the primary and upper elementary grades reported that they used basic elements of America's Choice like the 25 Book Campaign, standards, rubrics, and book logs. Four of the items, however, did contain substantial variation. These included use of class and individual student performance targets, a home/school notebook, and the use of the results of the New Standards Reference Examination to guide instruction. The high level of implementation of most of these items suggests that most of the teachers in the study were solid implementers of America's Choice.

Based on the items in Table 3, we developed a 10-point scale that represented the proportion of these items that teachers reported that they did. Thus, if a teacher reported that she did all of these activities, she received a score of 10 . On average, teachers reported implementing approximately 8 items on the 10 -item scale, while the standard deviation was approximately 1.5 items. We then used this scale in a multilevel model as a predictor of student performance, controlling for student prior achievement, student demographic characteristics, and teacher demographic characteristics.

\section{Table 3. Percent of Primary and Upper Elementary Teachers Reporting Use of Different Components of America's Choice}

\begin{tabular}{lcc}
\hline Survey ltem & $\begin{array}{c}\text { Primary } \\
\text { Grades } \\
\text { (grades 2-3) }\end{array}$ & $\begin{array}{c}\text { Upper Elementary } \\
\text { Grades } \\
\text { (grades 4-6) }\end{array}$ \\
\hline Post performance standards in classroom & $98 \%$ & $98 \%$ \\
Use standards to plan for instruction & 95 & 96 \\
Use 25 Book Campaign & 94 & 96 \\
Post models of student work that meet the standards in classroom & 90 & 94 \\
Students use rubrics to assess their work & 90 & 90 \\
Students use book logs to track what they have read & 90 & 98 \\
Have performance targets for each class & 76 & 76 \\
Have individual performance targets for each student & 70 & 59 \\
Use a home/school notebook to communicate with parents & 60 & 72 \\
Use the results from the New Standards Reference Exam to guide & 41 & 73 \\
instruction & & \\
\hline
\end{tabular}


Table 4. Results of Model Predicting Student Achievement Gains by the Extent of Teacher Overall Implementation of America's Choice

\begin{tabular}{lcc}
\hline Predictor Variable & $\begin{array}{c}\text { Primary } \\
\text { Grades } \\
\text { (grades 2-3) }\end{array}$ & $\begin{array}{c}\text { Upper Elementary } \\
\text { Grades } \\
\text { (grades 4-6) }\end{array}$ \\
\hline America's Choice overall implementation & .04 & $.06^{*}$ \\
\hline
\end{tabular}

$p<.10, " p<.05, " p<.01$

The results of our multi-level model that examined the relationship between teachers' overall implementation of America's Choice and student learning gains, after controlling for student and teacher demographic characteristics, are shown in Table 4. The full model is shown in Appendix D. For upper elementary students (grades 4-6), there was, on average, a statistically significant advantage to being in a class with a teacher who reported higher implementation of the different components of America's Choice. On average, each additional element that a teacher reported implementing was associated with one-sixteenth of a standard deviation gain in student learning. For example, all other things being equal, the students whose teacher reported implementing all 10 elements of America's Choice were predicted to perform a third of a standard deviation higher than a teacher who reported implementing 5 of the 10 elements of America's Choice. This difference in student performance was equivalent to a $1 \%$ increase in the number of correct responses for every unit of increased implementation. While there was a positive relationship between teacher implementation and primary grade student learning, this difference was not statistically significant.

The relationship between overall teacher implementation of America's Choice and gains in student learning is shown in Figure 1. In the figure, the lines represent the predicted learning gains of the average student with the average teachers with different levels of overall implementation of America's Choice. The dashed line represents the non-significant learning gains for students in grades 2 and 3 .
The solid line represents the statistically significant predicted learning gains for students in grades 4-6 associated with overall implementation of America's Choice. Several additional observations are apparent from the figure. First, the minimum number of America's Choice elements that were implemented by any teacher were 4 , while the maximum number was all 10 (suggesting the possibility of a ceiling effect). Second, the average student achieved the average gain in performance when her teacher implemented eight America's Choice elements.

\section{Predictors of Teachers' Overall Implementation of America's Choice}

Having established a relationship between overall implementation of America's Choice and student learning, we sought to explore what teacher characteristics were associated with teacher implementation of America's Choice. In other words, we sought to identify whether teachers with certain characteristics were more or less likely to implement America's Choice. Because these analyses were based solely upon survey data, we were also able to examine the relationship between teacher characteristics and teacher implementation of America's Choice both for Plainfield teachers as well as for teachers in America's Choice schools across the nation. The results of these analyses, both for Plainfield teachers and the national sample of America's Choice teachers, are shown in Table 5 . The units of each of the coefficients in the table are items on the 10-point scale of overall teacher implementation of America's Choice. 


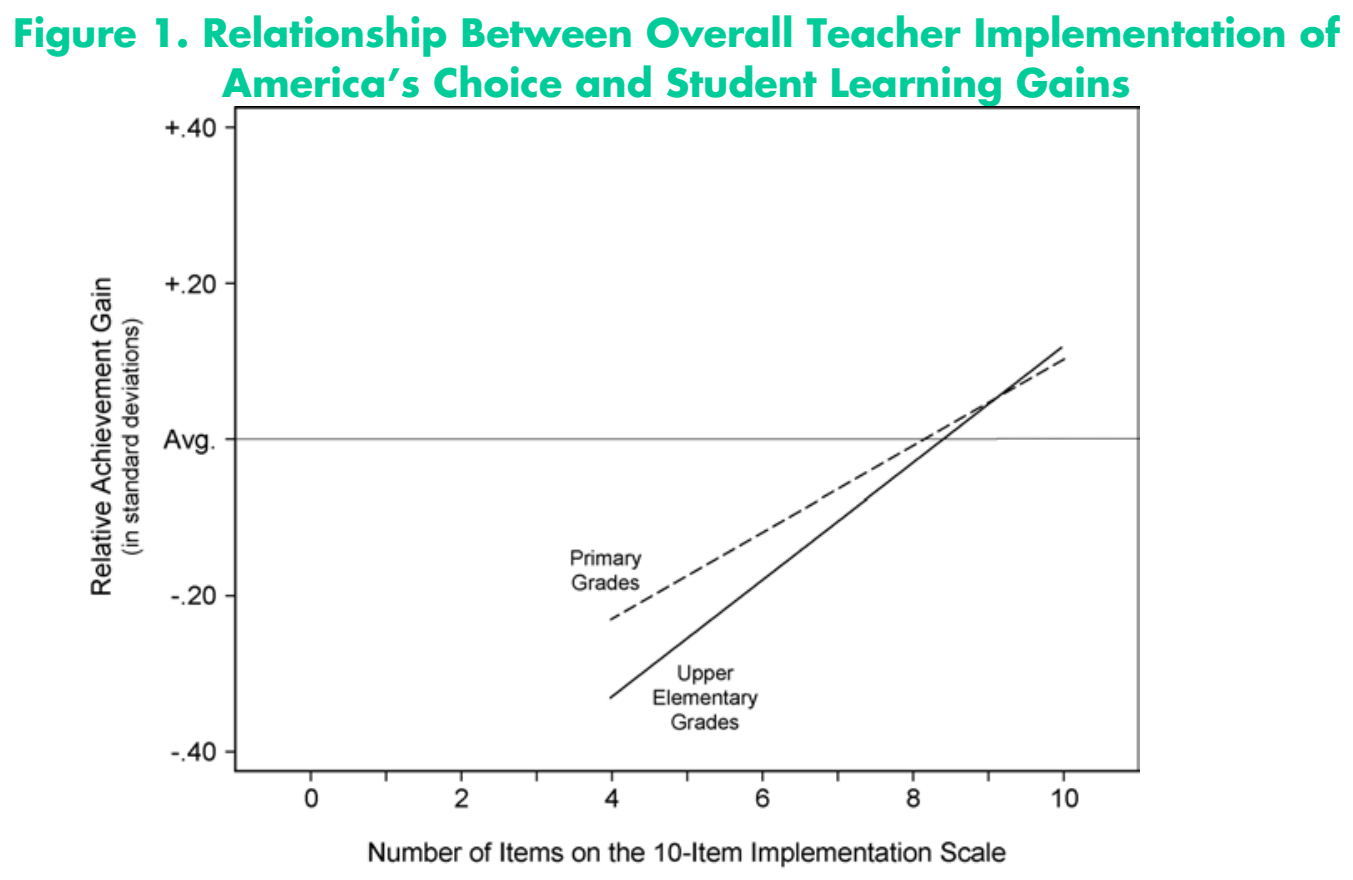

In the national sample, but not in Plainfield, female teachers were more likely than male teachers to implement America's Choice, as measured by the 10-point overall implementation scale. On average, female teachers nationally implemented three-quarters more of an item than did male teachers. In both Plainfield and nationally, African American teachers were more likely than were teachers of other ethnicities to implement aspects of America's Choice, as reflected in the 10-item scale. On average, African American teachers in Plainfield implemented three-quarters of an item more than did other ethnic teachers in the district. Nationally, African American teachers implemented about half an item more than did teachers of other ethnicities. In the national sample, but not in Plainfield, there was a statistically significant difference in the implementation of teachers who reported they were certified to teach the subject they reported teaching (in these cases either general elementary, English/language arts, reading, or writing) and those who reported they were not certified in the subject they taught. Subjectcertified teachers in the national America's Choice sample reported implementing .38 of an item more than did non-subject-certified teachers. Finally, there was no difference, either in Plainfield or nationally, between the self- reported implementation of America's Choice and teachers' experience.

We also examined the relationship between two classroom characteristics and teachers' overall implementation of America's Choice. In both Plainfield and nationally, teachers who reported that they were class teachers had higher levels of overall implementation of America's Choice than did teachers who were not class teachers. Being a class teacher was associated with about one-and-a-half more items of implementation on the 10-point implementation scale. There was no statistical relationship between class size and teachers' overall implementation of America's Choice either in Plainfield or nationally.

Our final set of investigations looked at the relationship between two representations of teacher attitudes - belief that all students can learn and belief that the same standards should be applied to all students - and overall implementation of America's Choice. In these investigations, we found relationships on both representations in the national sample but not in Plainfield. For America's Choice teachers nationally, every one-category increase in their 
Table 5. Teacher and School Characteristics Predicting Overall America's Choice Implementation

\begin{tabular}{|c|c|c|}
\hline Predictor Variable & $\begin{array}{c}\text { Plainfield } \\
\text { Teachers } \\
(n=114)\end{array}$ & $\begin{array}{c}\text { All } \\
\text { Teachers } \\
(n=1,177)\end{array}$ \\
\hline \multicolumn{3}{|l|}{ Teacher Background Characteristics } \\
\hline Female teachers vs. male teachers & $\begin{array}{l}.08 \\
(.51)\end{array}$ & $\begin{array}{l}.74^{* * *} \\
(.19)\end{array}$ \\
\hline African American vs. other teachers & $\begin{array}{l}.76^{*} \\
(.36)\end{array}$ & $\begin{array}{l}.54^{* * *} \\
(.16)\end{array}$ \\
\hline Subject-certified vs. non-subject-certified teachers & $\begin{array}{l}.49 \\
(.97)\end{array}$ & $.38^{*}$ \\
\hline Years of experience $^{a}$ & $\begin{array}{l}.01 \\
(.02)\end{array}$ & $\begin{array}{l}-.03 \\
(.07)\end{array}$ \\
\hline Classroom Characteristics & & \\
\hline Class teachers vs. other teachers & $\begin{array}{l}1.59 * * * \\
(.30)\end{array}$ & $\begin{array}{l}1.28 * * * \\
(.13)\end{array}$ \\
\hline Class size $^{a}$ & $\begin{array}{l}.01 \\
(.04)\end{array}$ & $\begin{array}{l}-.02 \\
(.07)\end{array}$ \\
\hline $\begin{array}{l}\text { Teacher Attitudes } \\
\text { Belief that all students can learn }\end{array}$ & $\begin{array}{l}.13 \\
(.40)\end{array}$ & $\begin{array}{l}.45^{* * *} \\
(.14)\end{array}$ \\
\hline $\begin{array}{l}\text { Belief that the same standards should be applied to } \\
\text { all students }{ }^{b}\end{array}$ & $\begin{array}{l}.03 \\
(.26)\end{array}$ & $.22^{*}$ \\
\hline
\end{tabular}

response on our four-point scale of whether they believed all their students can learn was associated with about a half an item increase on the 10-point scale of overall teacher implementation of America's Choice. Every one-category increase in their agreement on the scale of whether the same standards should be applied to all students was associated with about a quarter of a point increase on the 10-point scale of overall teacher implementation of America's Choice.

\section{Impact of Implementation of Writers Workshop on Student Learning}

In this section, we focus more specifically on teachers' implementation of writers workshop and its influence on student learning as measured by the New Jersey state tests. We examine the influence of two aspects of writers workshop: the time teachers have been teaching the America's Choice writers workshop strategy and their feelings of preparation to teach writers workshop.

Both time spent teaching writers workshop and preparation to teach writers workshop were survey items included in CPRE's survey of America's Choice teachers. As shown in Figure 2 , the majority of Plainfield teachers, $52 \%$ of primary teachers and $56 \%$ of upper elementary teachers, reported that they had been teaching writers workshop for more than one year. Given that most of these schools were in their second year of America's Choice, this is consistent with the rollout strategy of the design. About $20 \%$ of the teachers reported that they had been teaching writers workshop for almost one year. About $10 \%$ of primary teachers and $20 \%$ of upper elementary teachers reported that they had been teaching writers workshop for about a quarter of the school year. 
Educational researchers have long debated the best way to capture instructional practice on a survey instrument. By all accounts, it is very difficult to gather a direct representation of teachers' implementation of instruction through questions on a survey. For example, if one asks about the quantity of certain kinds of practice (like frequency of mini-lessons, conferencing with students, etc.), this raises questions about whether more is always better than less and says nothing of the quality with which these things are done. Because of these problems, rather than trying to directly measure implementation, we chose a more indirect strategy. We chose to measure how prepared teachers felt to implement writers workshop. This is based on the idea that, all things being equal, those teachers who felt more prepared to implement the workshop had done so more faithfully.

T Triters workshop opens with a short mini-lesson of about 7-10 minutes. There are three kinds of mini-lessons: procedural, craft, and skills. Procedural mini-lessons specifically focus on the rituals and routines of the writers workshop. Craft mini-lessons are geared to teach the strategies that authors use to produce effective writing like technique, style, and genre. Skills mini-lessons address the conventions of English like spelling, capitalization, punctuation, and paragraphs. Skills minilessons often incorporate student writing by using examples of student written work where conventions need to be reviewed. An independent work period, lasting 35-45 minutes, should follow in which students are engaged in the writing process, including planning, drafting, revising, editing, and polishing/publishing. Students work either individually or in small groups. Response groups provide students with an opportunity to elicit feedback on drafts from a partner or small group of peers. Writers workshop ends with a short (five minute) closure session, frequently author's chair, in which individual students share selections of their work in progress. In Plainfield, writers workshop was introduced in year one in elementary schools and year two in middle schools.

Figure 2. Time Plainfield Teachers Reported Teaching Writers Workshop

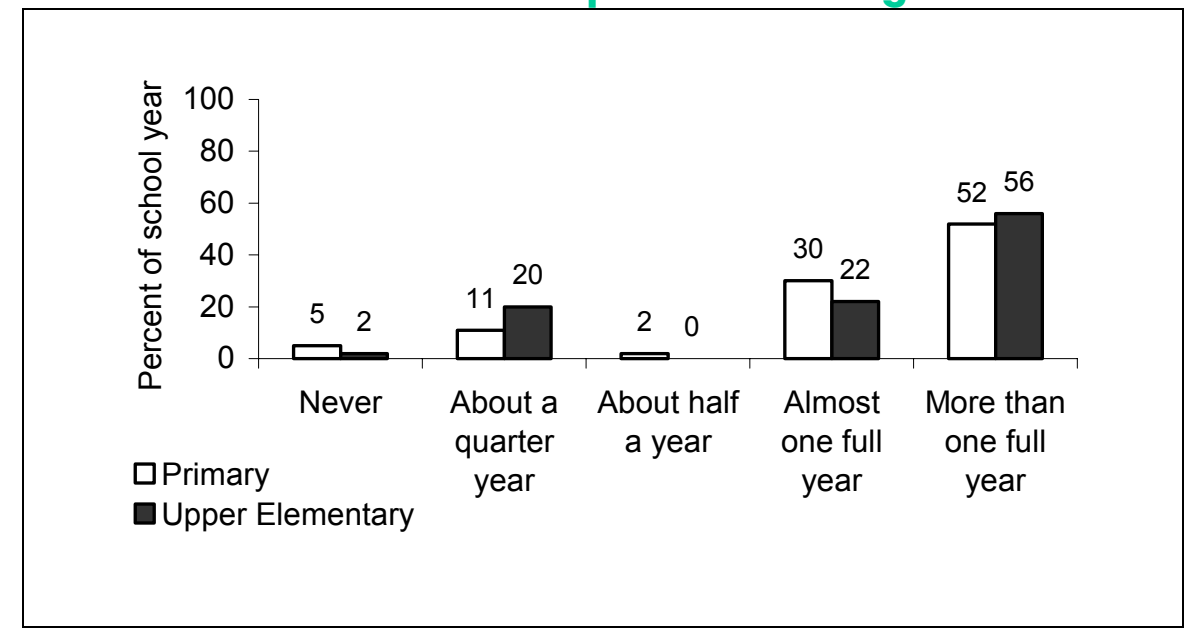




\section{Figure 3. Plainfield Teachers' Preparation to Teach Writers Workshop}

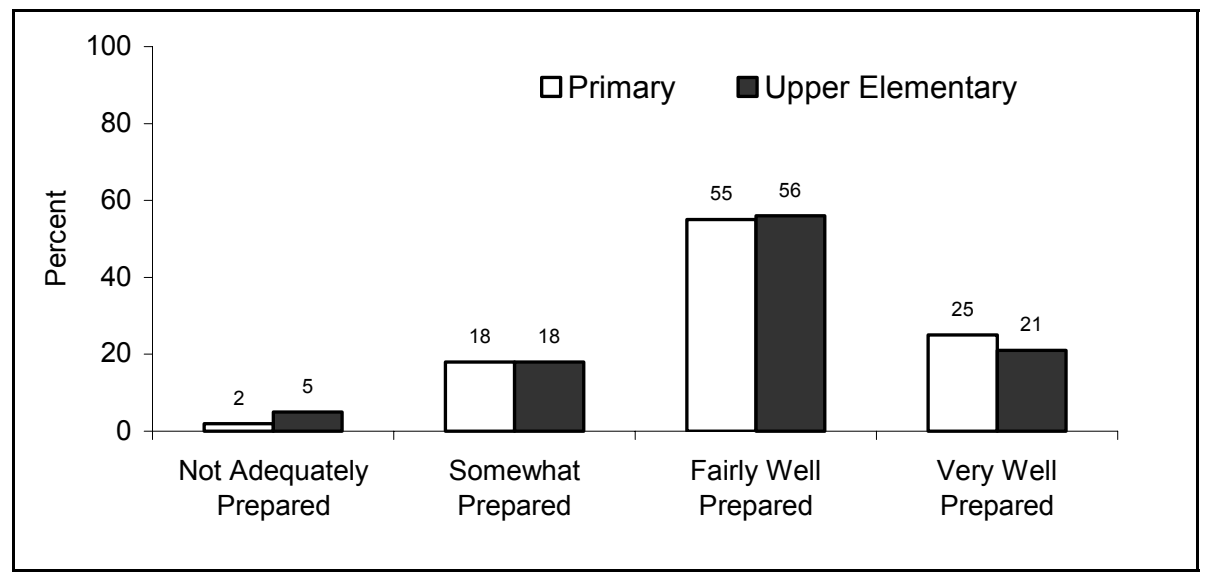

Figure 3 shows teachers' responses to the survey question about how prepared they felt to implement writers workshop. Just over half the teachers, at both the primary and upper elementary grades, reported that they felt fairly well prepared to teach writers workshop. About $25 \%$ of primary grade teachers and about $20 \%$ of upper elementary grade teachers said they felt very well prepared to teach writers workshop. Most of the remaining 20\% reported that they felt somewhat prepared, while very few teachers reported that they were not adequately prepared to teach writers workshop.

Using these survey data, we then examined the relationship between the time teachers reported teaching writers workshop and their feelings of preparation to teach writers workshop and student learning. The results of these analyses are shown in Table 6. The full models are shown in Appendices $\mathrm{E}$ and $\mathrm{F}$.

There was only a very small relationship between the time that teachers reported teaching writers workshop and student learning. In grades 4-6, this relationship was statistically significant, but substantially small, with each approximately half year of time teaching writers workshop only associated with four-hundredths of a standard deviation increase in student learning.
Teachers' self-reported preparation to teach writers workshop was associated with a statistically significant and more robust fifth of a standard deviation increase in student learning. In other words, for each additional unit increase in preparation that a teacher reported, her students' learning was between .14 to .19 of a standard deviation higher than that of the average student. This translates to a $2 \%$ to $3 \%$ increase in the number of correct items on the state test for every unit of increased preparation to teach writers workshop. In other words, the average student of the average teacher who reported that she was very well prepared to teach writers workshop answered $8 \%$ to $12 \%$ more items correctly than did the average student of the average teacher who reported that she was not adequately prepared to teach writers workshop.

The relationships between teachers' feelings of preparation to teach writers workshop and student learning gains are shown graphically in Figure 4. At both the primary and upper elementary grade ranges, there was a positive and statistically significant relationship between gains in student learning and teachers' feelings of preparation to teach writers workshop. 
Table 6. Results of Model Predicting Student Achievement Gains by the Extent of Teacher Implementation of Writers Workshop

\begin{tabular}{|c|c|c|}
\hline Predictor Variable & $\begin{array}{c}\text { Primary } \\
\text { Grades } \\
\text { (grades 2-3) }\end{array}$ & $\begin{array}{c}\text { Upper } \\
\text { Elementary } \\
\text { Grades } \\
\text { (grades 4-6) }\end{array}$ \\
\hline Time teaching writers workshop & $\begin{array}{c}.02 \\
(.02)\end{array}$ & $\begin{array}{l}.04 \sim \\
(.02)\end{array}$ \\
\hline Preparation to teach writers workshop & $\begin{array}{l}.14 \sim \\
(.08)\end{array}$ & $\begin{array}{l}.19^{*} \\
(.08)\end{array}$ \\
\hline
\end{tabular}

$p<.10, p<.05, " * p<.01,{ }^{\prime \prime *} p<.001$

The students of teachers who reported that they were fairly well prepared to teach writers workshop represented the average learning gains of the sample. Those students of teachers who reported being not adequately prepared or only somewhat prepared to teach writers workshop had below-average gains in test score performance. Students of teachers who reported that they were very well prepared to teach writers workshop scored about a fifth of a standard deviation higher in test performance than did the average student.

\section{Predictors of Teachers' Preparation to Teach Writers Workshop}

Once we had established a relationship between teachers' feelings of preparation to teach writers workshop and student learning gains, we sought to examine what teacher characteristics were associated with teacher preparation to teach writers workshop. Using data from the CPRE survey, we explored the relationship between a variety of teacher background, classroom, and attitudinal characteristics and teacher selfreported preparation to teach writers workshop.

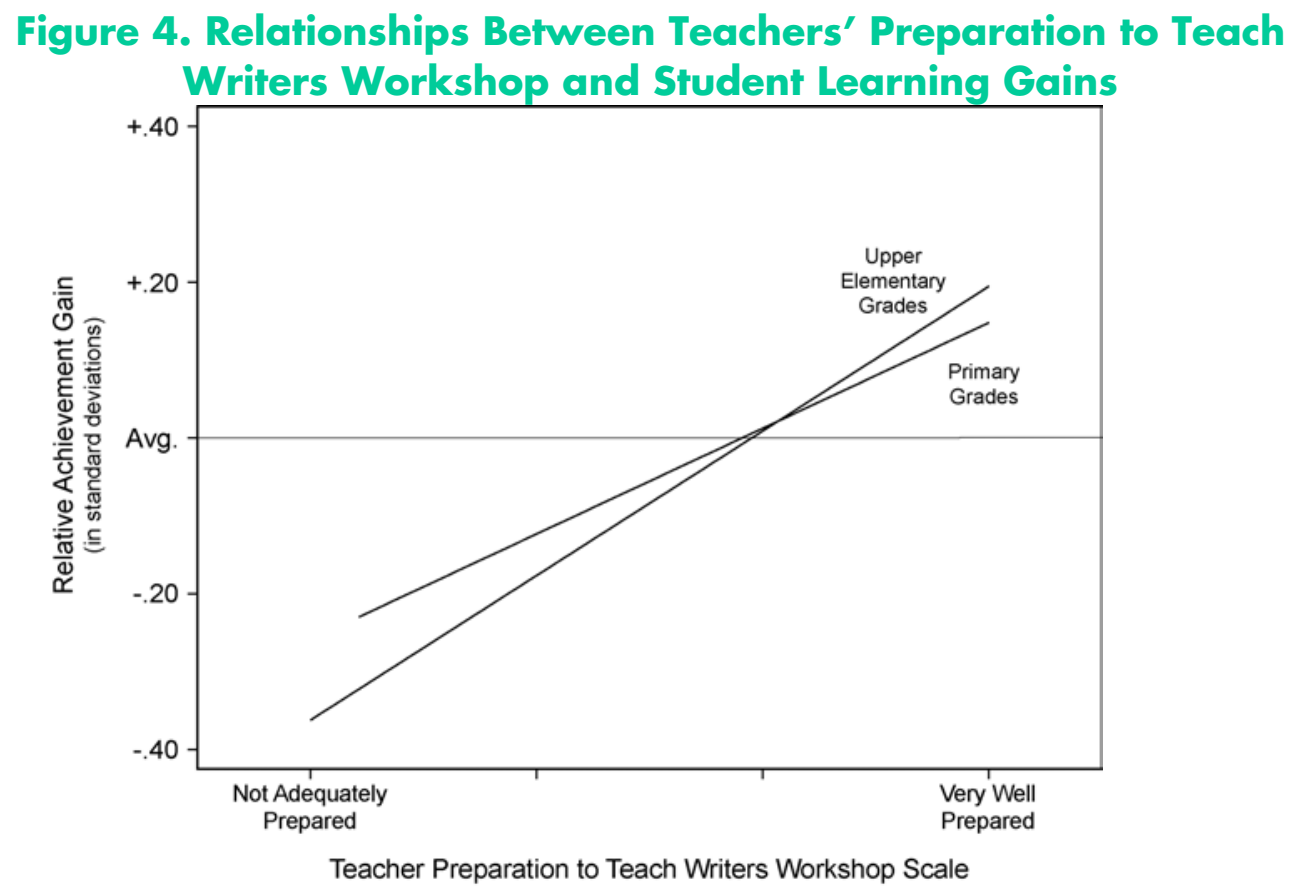


Table 7. Teacher and School Characteristics Predicting Teacher Preparation to Teach Writers Workshop

\begin{tabular}{|c|c|c|}
\hline Predictor Variable & $\begin{array}{l}\text { Plainfield } \\
\text { Teachers } \\
(n=114)\end{array}$ & $\begin{array}{c}\text { All } \\
\text { Teachers } \\
(n=1,177)\end{array}$ \\
\hline \multicolumn{3}{|l|}{ Teacher Background Characteristics } \\
\hline Female teachers vs. male teachers & $\begin{array}{l}.04 \\
(.20)\end{array}$ & $\begin{array}{l}.07 \\
(.10)\end{array}$ \\
\hline African American vs. other teachers & $\begin{array}{l}.18 \\
(.16)\end{array}$ & $\begin{array}{l}.24^{* *} \\
(.07)\end{array}$ \\
\hline Subject-certified vs. non- subject-certified teachers & $\begin{array}{l}.22 \\
(.34)\end{array}$ & $\begin{array}{l}-.12 \\
(.12)\end{array}$ \\
\hline Years of experience $^{a}$ & $\begin{array}{l}.01 \\
(.01)\end{array}$ & $\begin{array}{l}.04 \\
(.03)\end{array}$ \\
\hline \multicolumn{3}{|l|}{ Classroom Characteristics } \\
\hline Class teachers vs. other teachers & $\begin{array}{l}.10 \\
(.14)\end{array}$ & $\begin{array}{l}.04 \\
(.06)\end{array}$ \\
\hline Class size $^{a}$ & $\begin{array}{l}.01 \\
(.02)\end{array}$ & $\begin{array}{l}-.01 \\
(.03)\end{array}$ \\
\hline $\begin{array}{l}\text { Teacher Attitudes } \\
\text { Belief that all students can learn }\end{array}$ & $\begin{array}{l}.38^{*} \\
(.15)\end{array}$ & $\begin{array}{l}.32^{* * *} \\
(.06)\end{array}$ \\
\hline $\begin{array}{l}\text { Belief that the same standards should be applied to } \\
\text { all students }\end{array}$ & $\begin{array}{l}.10 \\
(.11)\end{array}$ & $\begin{array}{l}.09^{*} \\
(.04)\end{array}$ \\
\hline
\end{tabular}

The results of these investigations are shown in Table 7. The results are displayed for Plainfield teachers and a comparable sample of teachers in America's Choice schools across the nation. The coefficients in the table show the change in the four-point scale of preparation.

The first set of analyses examined the relationship between teachers' background characteristics, including ethnicity, gender, experience, and certification status, and their preparation to teach writers workshop. Of these four teacher background characteristics, only ethnicity was related to teacher preparation to teach writers workshop. In the national sample (but not in Plainfield), African American teachers, who represented $21 \%$ of the sample, reported feeling more prepared to teach writers workshop than did teachers of other ethnicities.

We also examined the relationship between two aspects of classroom characteristics (class teacher and class size) and teachers' preparation to teach writers workshop. There was no statistical relationship between teachers who were class teachers and their preparation to teach writers workshop in either the national sample or in Plainfield. Likewise, the size of teachers' classes was not associated with their selfreported preparation to teach writers workshop either in Plainfield or nationally.

Our final set of analyses examined the relationship between two aspects of teacher attitudes and instructors' feelings of preparation to teach writers workshop. In both the Plainfield and national samples of teachers, we found a positive and statistically significant relationship between teachers' beliefs that all students can learn and their self-reported preparation to teach writers workshop. Each one-category increase in their response on our four-point scale of whether they believed all their students can learn was associated with about a third of a point increase 
in the four-point scale of preparation to teach writers workshop. In other words, teachers who believe that all of their students can learn felt more prepared to teach writers workshop.

In the larger national sample of teachers, but not in the Plainfield group of teachers, there was a smaller, but still statistically significant, relationship between teachers' belief that the same standards should be applied to all students and their feelings of preparation to teach writers workshop. That is, teachers who believed that the same standards should be applied to all of their students were inclined to report higher levels of preparation to teach writers workshop.

\section{Impact of Implementation of Readers Workshop on Student Learning}

In this section, we examine the relationship between Plainfield teachers' implementation of readers workshop and gains in their students' New Jersey state test performance. We focus on two aspects of readers workshop: the time that teachers report teaching the America's Choice readers workshop instructional approach and their feelings of preparation to teach readers workshop. eaders workshop is structured to begin with a whole-class meeting in which the class might do a shared reading and have a mini-lesson in a 15-20 minute time period. The mini-lesson can cover phonics-based skills, decoding word analysis, comprehension skills, or procedures. This mini-lesson is usually followed by a period of independent/guided reading and/or reading conference period in which a number of activities like partner reading or book talks occur for about 45 minutes. In independent reading, students focus on reading appropriately leveled texts for enjoyment and understanding. Partner reading allows students to work with slightly more difficult texts, practice reading aloud, and model "accountable talk" and "think-aloud" strategies. Reading aloud provides an opportunity for the teacher or other proficient reader to introduce authors or topics and model reading for the whole class. Shared reading allows the teacher to work with smaller groups of readers on reading strategies. Readers workshop may end with a book talk in which students share reactions to books read independently or to a book read aloud to the group. In Plainfield, readers workshop was introduced in year one in middle schools and year two in elementary schools.

\section{Figure 5. Time Plainfield Teachers Reported Teaching Readers Workshop}

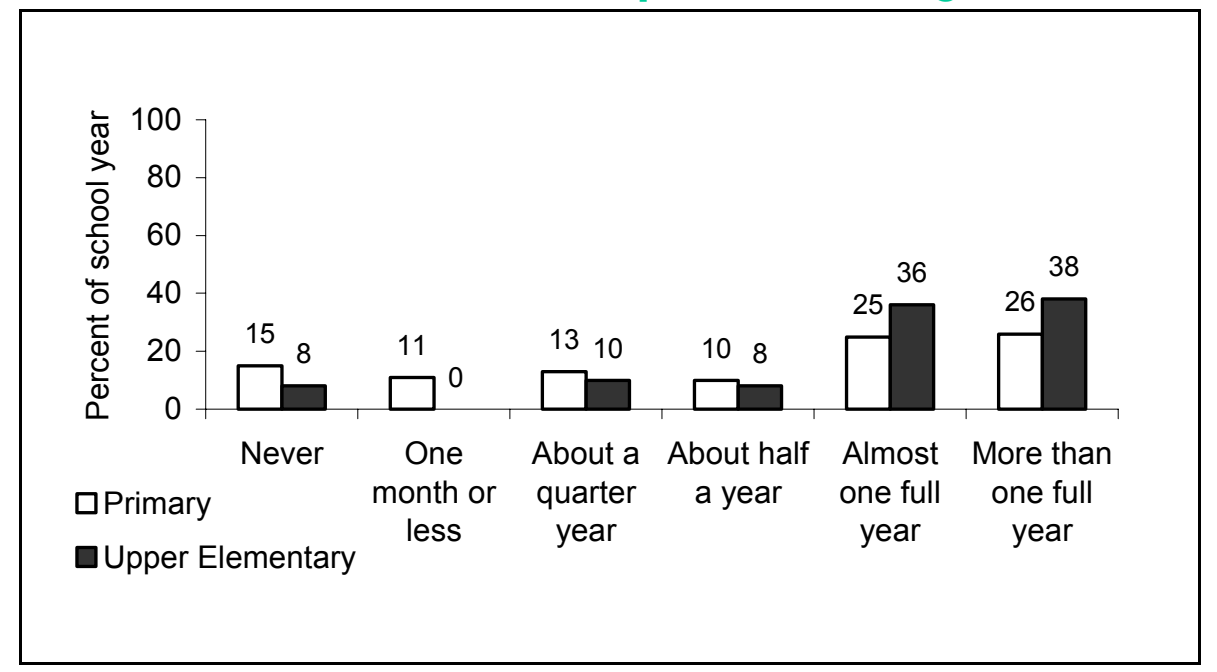


The rollout of America's Choice in Plainfield called for teachers to implement readers workshop in the second year of the design. Therefore, it is not surprising that teachers reported lower levels of implementation of readers workshop in comparison to their implementation of writers workshop. The time Plainfield teachers reported teaching readers workshop is shown in Figure 5. Thirty-eight percent of upper elementary (grades 4-6) teachers and $26 \%$ of primary (grades $1-3$ ) teachers reported teaching readers workshop for more than one year. A quarter of primary grade teachers and $36 \%$ of upper elementary grade teachers reported teaching readers workshop for almost a full year. About $10 \%$ of teachers reported teaching readers workshop for about half a school year and an additional $10 \%$ reported teaching readers workshop for about a quarter of the school year. About a quarter of the primary grade teachers said that they had taught readers workshop for one month or less, while $8 \%$ of upper elementary teachers indicated that they taught readers workshop for one month or less. The higher level of time implementing readers workshop in the upper elementary grades is an artifact of the longer implementation in sixth grade in Plainfield, where readers workshop was implemented beginning in year one.

Those teachers who reported that they had taught readers workshop were also asked to indicate their feelings of preparation to teach readers workshop on a four-point scale ranging from very well prepared to not adequately prepared. Teachers' responses are shown in Figure 6 . Approximately $20 \%$ of the teachers in both the primary and upper elementary grades responded that they felt very well prepared to teach readers workshop. Just over half $(51 \%)$ of the primary grade teachers and about a third $(36 \%)$ of the upper elementary teachers reported that they were fairly well prepared to teach readers workshop. About a third of the teachers at each grade range said that they were only somewhat prepared to teach readers workshop. Finally, just $2 \%$ of primary teachers and $10 \%$ of upper elementary teachers said that they were not adequately prepared to teach readers workshop.

\section{Figure 6. Plainfield Teachers' Preparation to Teach Readers Workshop}

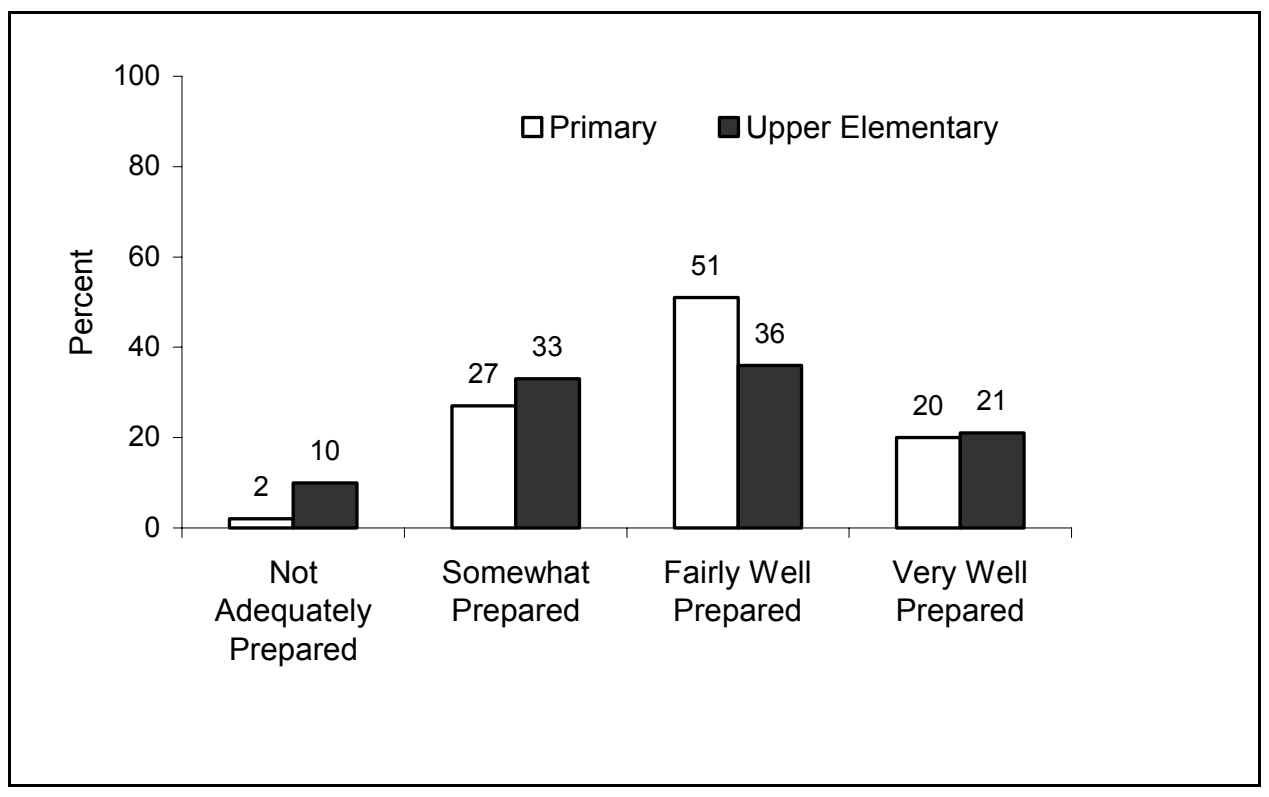


Table 8. Results of Model Predicting Student Achievement Gains by the Extent of Teacher Implementation of Readers Workshop

\begin{tabular}{lcc}
\hline & Primary & $\begin{array}{c}\text { Upper } \\
\text { Elementary } \\
\text { Grades }\end{array}$ \\
Predictor Variable & $\begin{array}{c}\text { Grades } \\
\text { (grades 2-3) }\end{array}$ & \begin{tabular}{c} 
(grades 4-6) \\
\hline Time teaching readers workshop
\end{tabular} \\
Preparation to teach readers workshop & -.02 & .02 \\
& $(.02)$ & $.02)$ \\
& .08 & $.16^{*}$ \\
\hline
\end{tabular}

$p<.10,{ }^{*} p<.05,{ }^{* *} p<.01,{ }^{* * *} p<.001$

Based upon these survey responses, we then examined the relationship between these two indicators of teachers' implementation of readers workshop and the learning gains of their students. The results of these analyses are shown in Table 8 and the full models are shown in Appendices $\mathrm{G}$ and $\mathrm{H}$. There was no statistical relationship between the time that teachers spent teaching readers workshop and their students' learning gains. That is, students performed similarly on the end-of-year state test, after controlling for their prior achievement and background characteristics, regardless of the amount of time that their teacher reported teaching readers workshop.

There were, however, differences in student learning gains associated with teachers' reported preparation to teach readers workshop. In the upper elementary grades, after controlling for prior achievement and student background characteristics, every increased unit of preparation reported by a teacher was associated with one-sixth of a standard deviation higher than average student test score gains. The relationship between primary teacher preparation to teach readers workshop and student learning gains was also positive, but was not statistically significant.

The positive and significant (in the case of upper elementary teachers and their students) relationship between teacher preparation to teach readers workshop and student test performance gains is graphically shown in Figure 7. The dashed line represents the non-significant differences in the learning gains for students in grades 2 and 3 associated with their teachers' feelings of preparation to implement readers workshop. The solid line represents the statistically significant learning gains for students in grades 4-6 associated with their teachers' self-reported preparation to teach readers workshop. Each additional unit of preparation to teach readers workshop that teachers reported translates into $2.6 \%$ more correct test answers for their students on the state test.

\section{Predictors of Teachers" Preparation to Teach Readers Workshop}

Now that we knew that upper elementary teachers' preparation to teach readers workshop was positively associated with students gains, we were interested in exploring what teacher characteristics were associated with teachers' preparation to teach readers workshop. Table 9 shows the results of a series of simple regression analyses examining the relationship between teacher background, classroom and attitudinal characteristics, and teachers' self-reported preparation to teach readers workshop. 


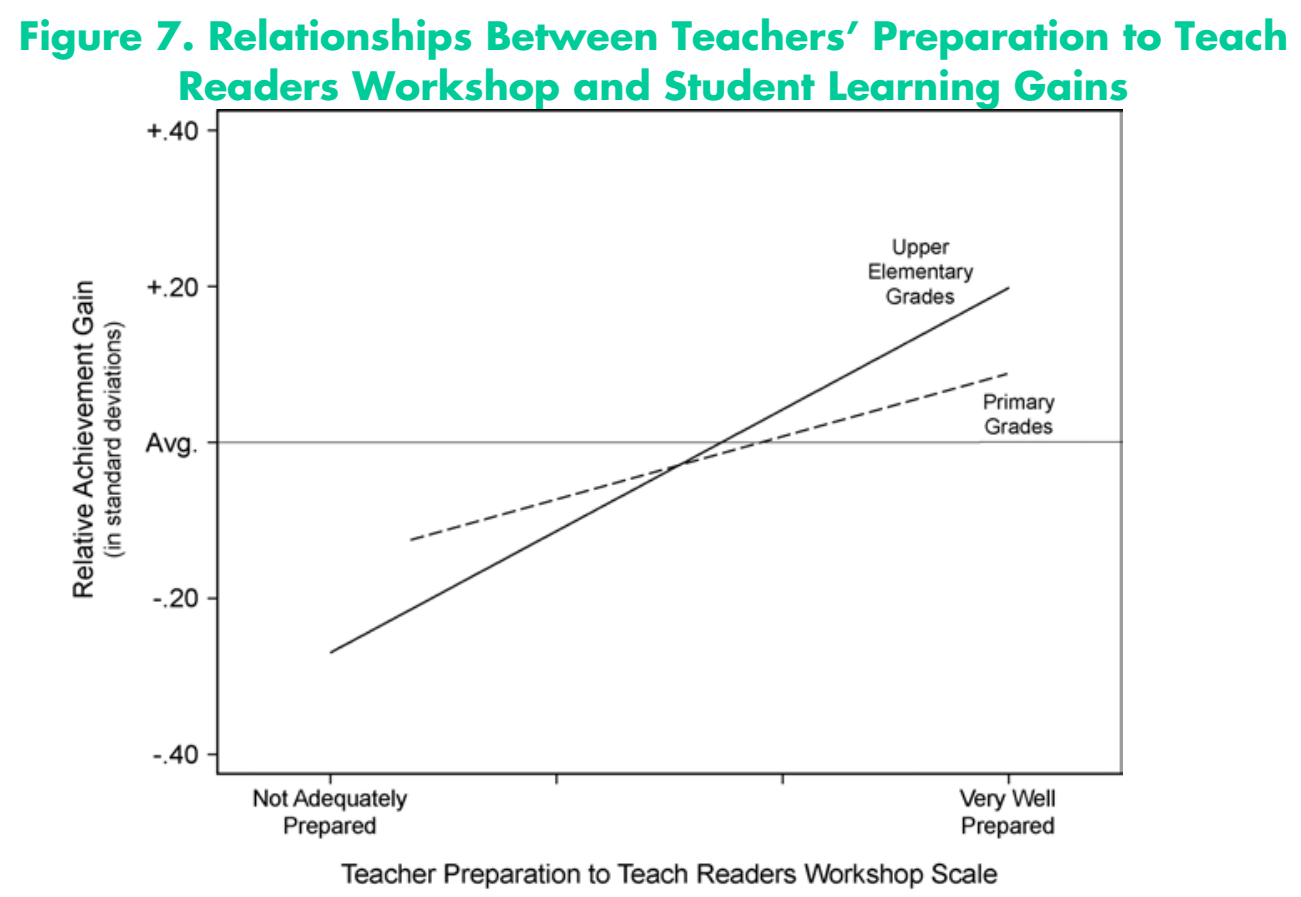

None of the examined background characteristics of Plainfield teachers was related to teachers' preparation to teach readers workshop. In the national sample, as with writers workshop, African American teachers reported that they were more prepared to teach readers workshop than did teachers of other ethnicities. In the national sample, there was also a significant relationship between teachers' experience and preparation to teach readers workshop. On average, for every standard deviation increase in teachers' years of experience, instructors were .12 of a category more prepared to teach readers workshop.

Teachers who indicated that they were class teachers reported a similar distribution of preparation to teach readers workshop as did teachers who were not class teachers. In the national sample, but not in Plainfield, there was a negative relationship between class size and teachers' preparation to teach readers workshop. On average, for every standard deviation increase in the size of a teacher's class, teachers reported being .14 of a category less prepared to teach readers workshop.

There was a clear relationship between teachers' preparation to teach readers workshop and attitudes consistent with the philosophy of
America's Choice. In both Plainfield and the national sample, teachers who agreed with statements consistent with the belief that all students could learn reported being more prepared to teach readers workshop. Likewise in Plainfield, but not in the national sample, there was a relationship between teachers who believed that all students should be held to the same standards and preparation to teach readers workshop.

\section{Impact of Teachers' Beliefs on Student Learning}

The stated mission of America's Choice is to help teachers to prepare all students, except the most severely handicapped, to reach high standards of performance. Underlying this is the philosophical belief that all teachers must believe that all students are capable of reaching standards. Two sets of survey questions were designed to assess teachers' beliefs about student learning capabilities. The first teacher belief was the seven-item scale that gauged teachers' beliefs about the learning capabilities of all of their students. The second teacher belief was the four-item scale that assessed teachers' beliefs that all students should meet high standards of performance. 
Table 9. Teacher and School Characteristics Predicting Teacher Preparation to Teach Readers Workshop

\begin{tabular}{|c|c|c|}
\hline Predictor Variable & $\begin{array}{l}\text { Plainfield } \\
\text { Teachers } \\
(n=114)\end{array}$ & $\begin{array}{c}\text { All } \\
\text { Teachers } \\
(n=1,177)\end{array}$ \\
\hline \multicolumn{3}{|l|}{ Teacher Background Characteristics } \\
\hline Female teachers vs. male teachers & $\begin{array}{l}-.03 \\
(.24)\end{array}$ & $\begin{array}{l}.24 \\
(.13)\end{array}$ \\
\hline African American vs. other teachers & $\begin{array}{l}.26 \\
(.17)\end{array}$ & $\begin{array}{l}.20^{*} \\
(.09)\end{array}$ \\
\hline Subject-certified vs. non-subject-certified teachers & $\begin{array}{l}.38 \\
(.38)\end{array}$ & $\begin{array}{l}.10 \\
(.13)\end{array}$ \\
\hline Years of experience $^{a}$ & $\begin{array}{l}.01 \\
(.01)\end{array}$ & $\begin{array}{l}.12 * * * \\
(.03)\end{array}$ \\
\hline Classroom Characteristics & & \\
\hline Class teachers vs. other teachers & $\begin{array}{l}-.04 \\
(.17)\end{array}$ & $\begin{array}{l}.09 \\
(.07)\end{array}$ \\
\hline Class size $^{a}$ & $\begin{array}{l}-.00 \\
(.02)\end{array}$ & $\begin{array}{l}-.14^{* *} \\
(.04)\end{array}$ \\
\hline $\begin{array}{l}\text { Teacher Attitudes } \\
\text { Belief that all students can learn }^{b}\end{array}$ & $\begin{array}{l}.55^{* *} \\
(.18)\end{array}$ & $\begin{array}{l}.29 * * * \\
(.07)\end{array}$ \\
\hline $\begin{array}{l}\text { Belief that the same standards should be applied to } \\
\text { all students }{ }^{\text {b }}\end{array}$ & $\begin{array}{l}.30^{*} \\
(.13)\end{array}$ & $\begin{array}{l}.03 \\
(.05)\end{array}$ \\
\hline
\end{tabular}

p $<.10,{ }^{*} p<.05,{ }^{* *} p<.01,{ }^{* * *} p<.001$

a Effect of a one standard deviation increase.

${ }^{b}$ Effect of a one-category increase on a four-point scale of agreement.

The scale of teachers' belief that all students can learn was constructed from responses to seven questions that asked teachers for their agreement with a series of statements designed to gauge teachers' beliefs about student learning. Items included questions about whether teachers believed most students were capable of learning the material that teachers were expected to teach, whether student success was based more on ability than effort, and whether students could work together without close supervision. A complete list of the questions is provided in Appendix C. Figure 8 shows the distribution to the scale that measured teachers' beliefs that all students can learn. About $15 \%$ of respondents, on average, somewhat disagreed with the statements. About two-thirds somewhat agreed, and about $15 \%$, on average, strongly agreed.
The scale of teachers' belief that the same standards should apply to all students asked teachers for their agreement with a series of statements intended to assess their belief that all students should meet high standards of performance. Items included questions about whether teachers used the same criteria to judge the quality of student work, and whether special education students and English language learners should be held to the same standards as regular education students. A complete list of the questions is provided in Appendix C.

Figure 9 shows the distribution to the scale that measured teachers' beliefs that all students can learn. A few teachers strongly disagreed with these statements. About a quarter of upper elementary teachers and $12 \%$ of primary grade teachers somewhat disagreed with these statements, on average. About $60 \%$ of primary 
Figure 8. Plainfield Teachers' Belief that all Students Can Learn

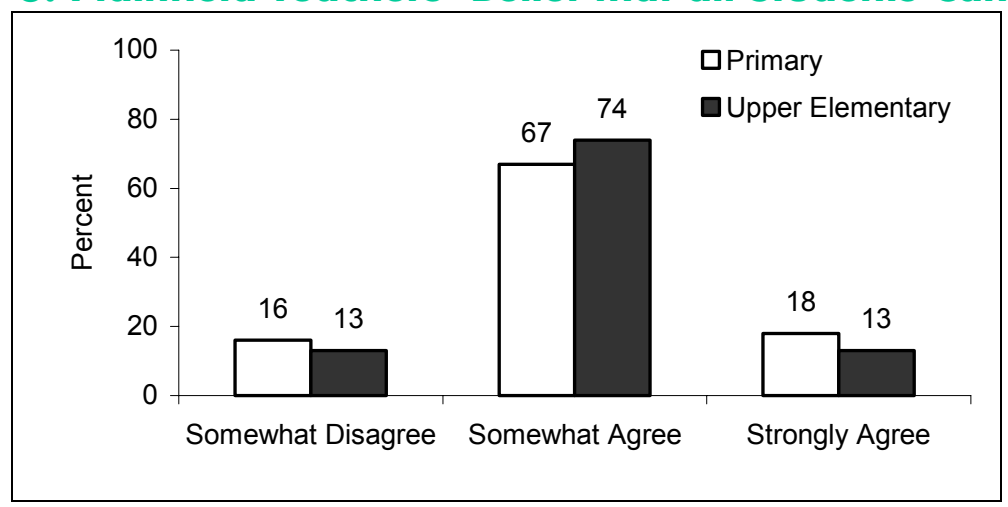

teachers and $45 \%$ of upper elementary teachers somewhat agreed with the statements that the same standards should apply to all students. Finally, about a quarter of teachers strongly agreed with these statements.

The final analyses that we conducted for this study were to explore the statistical relationships between these two aspects of teacher beliefs associated with the philosophy of America's Choice and student test gains. The results of our examination of the relationship between these two aspects of teachers' beliefs and the learning gains of their students are shown in Table 10. Appendices I and J contain the full models.

As shown in Table 10, we found no statistically significant evidence that teachers' beliefs about student capabilities, as measured by the survey questions focused on beliefs that all students can learn and that the same standards should be applied to all students, were associated with differential gains in student learning. More specifically, there was no systematic relationship between the variation in teacher responses to these survey questions and differences in student learning gains.

Figure 9. Plainfield Teachers' Belief that the Same Standards Should be Applied to all Students

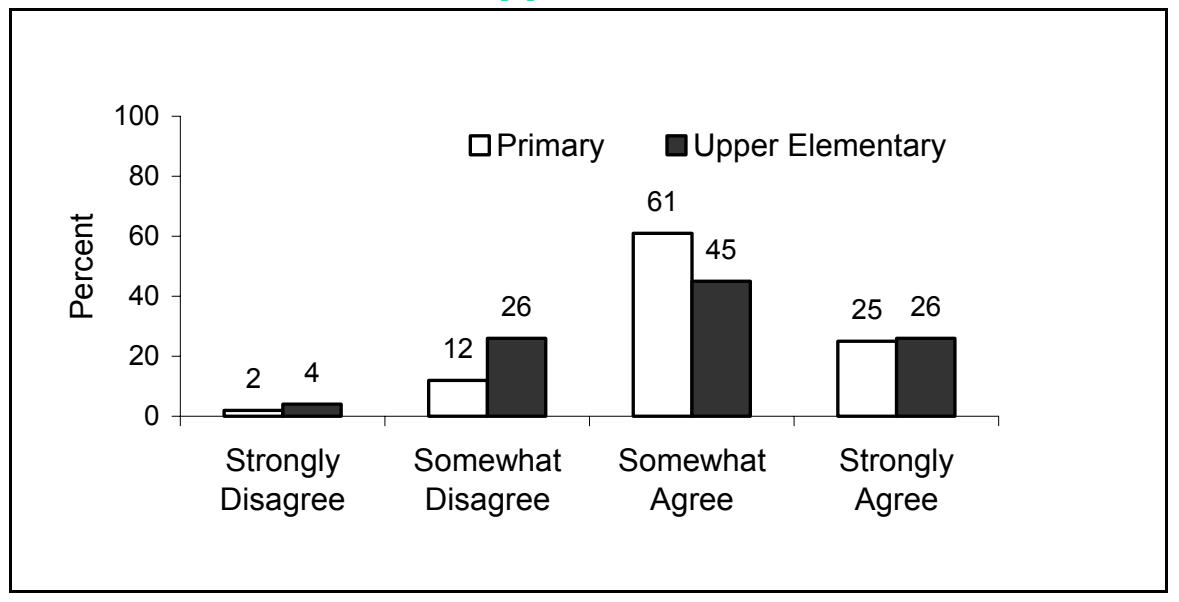




\section{Table 10. Results of Model Predicting Student Achievement} Gains by Teacher Beliefs

\begin{tabular}{lcc}
\hline Predictor Variable & $\begin{array}{c}\text { Upimary } \\
\text { Grades } \\
\text { (grades 2-3) }\end{array}$ & $\begin{array}{c}\text { Uper } \\
\text { Elementary } \\
\text { Grades } \\
\text { (grades 4-6) }\end{array}$ \\
\hline Belief that all students can learn & .04 & .06 \\
Belief that the same standards should be applied to all & $(.11)$ & $(.12)$ \\
students & .13 & .03 \\
\hline
\end{tabular}

\section{Summary}

Overall, there is ample evidence that various aspects of the implementation of America's Choice in Plainfield are associated with gains in student learning. Three dimensions of the implementation of America's Choice - overall implementation, and preparation to teach writers and readers workshop-were statistically associated with above-average gains in student learning.

The cumulative evidence from this study is summarized in Table 11. In the upper elementary grades, after controlling for student prior achievement and background characteristics, teacher overall implementation of America's Choice was associated with a statistically significant gain of .06 standardized deviation units. This translates to a $1 \%$ largerthan-average gain in student learning for every element of America's Choice that a teacher reported implemented. Thus, for example, the average learning gain of students of teachers who reported implementing all of the 10 elements of America's Choice that were included in the scale was $5 \%$ greater than the learning gain of students of teachers who reported implementing half of the 10 elements of America's Choice.

\section{Table 11. Summary of Study Results}

\begin{tabular}{lcc} 
Predictor Variable & $\begin{array}{c}\text { Primary } \\
\text { Grades } \\
\text { (grades 2-3) }\end{array}$ & $\begin{array}{c}\text { Upper Elementary Grades } \\
\text { (grades 4-6) }\end{array}$ \\
\hline America's Choice implementation & .04 & $.06^{*}$ \\
Time teaching writers workshop & $(.03)$ & $(.03)$ \\
Time teaching readers workshop & .02 & $.04 \sim$ \\
& $(.02)$ & $.02)$ \\
Writers workshop preparation & -.02 & .02 \\
Readers workshop preparation & $(.02)$ & $(.02)$ \\
& $.14 \sim$ & $.19^{*}$ \\
"All students can learn" & $(.08)$ & $(.08)$ \\
& .08 & $.16^{*}$ \\
"Same standards should apply to all & $(.08)$ & $.07)$ \\
students" & .04 & .06 \\
\hline P< & $(.11)$ & .03 \\
\hline
\end{tabular}


There was no evidence that the time that teachers had spent implementing either readers or writers workshop were related to larger gains in student learning. The payoff appeared to come when teachers felt comfortable implementing the workshops. Both for writers and readers workshop, there were significantly larger-than-average gains in student learning for those students whose teachers reported feeling more prepared to teach the workshops in comparison to the learning gains of the students of teachers who reported feeling less prepared to teach the workshops. These gains ranged from a $2.3 \%$ to $3.2 \%$ increase in the number of correct test answers for every unit of increasing preparation that teachers reported (on the fourpoint preparation scale). Thus, for example, all other things being equal, students of teachers who reported feeling very well prepared to teach the workshops had between $10.4 \%$ and $12.8 \%$ more correct answers than did students of teachers who reported feeling not adequately prepared to teach the workshops.

One of the patterns of results from this study that requires further exploration is the fact that detectable effects were more apparent in the upper elementary grades and less detectable in the primary grades. The results for readers workshop, which showed a relationship in the upper elementary grades but not in the primary grades, appear to shadow the rollout of the America's Choice design in Plainfield, which introduced reading earlier in upper elementary grades and later in primary grades. However, the pattern of effects amongst the other variables is less clear. None of the hypotheses we explored (sample sizes, response rates, teacher demographics) offered plausible explanations for the different patterns of results across grade levels. Other hypotheses, including inadequacies in our survey instruments, misalignments in the test measures, or lack of true equating of test scores, warrant further exploration.

Finally, we could detect no relationship between the responses of teachers to survey questions about their beliefs associated with the philosophy of America's Choice and the learning gains of their students. Neither teacher responses about their beliefs that all students can learn nor that the same standards should apply to all students were associated with differences in the learning gains of students. 


\section{References}

Goldhaber, D. D., \& Brewer, D. J. (2000). Does teacher certification matter? High school teacher certification status and student achievement. Educational Evaluation \& Policy Analysis, 22(2), 129-145.

Horn, J. L. (1965). A rationale and test for the number of factors in factor analysis.

Psychometrika, 30(2), 179-185.

Plainfield Public Schools. (n.d.). The mission statement of the Plainfield Public Schools.

Retrieved January 6, 2003, from

http://www.plainfieldnjk12.org/

Raudenbush, S., \& Bryk, A. (2002).

Hierarchical linear models: Applications and data analysis methods, second edition. London: Sage Publications. 
Appendix A. Comparison of Retained and Deleted Samples of Plainfield Teachers on Four Teacher Characteristics

\begin{tabular}{ccc}
\hline & Retained & Deleted \\
& Sample & Sample \\
Teacher Characteristic & of Teachers & of Teachers \\
& $(\mathrm{n}=114)$ & $(\mathrm{n}=267)$ \\
\hline
\end{tabular}

Teacher Gender

$\%$ Female
$\%$ Male
p-value

Teacher Ethnicity

$\%$ African American

$\%$ Hispanic

$\%$ White

$\%$ Other

p-value ${ }^{a}$

Certification

$\%$ of Teachers Certified

$\%$ of Teachers Not Certified

p-value ${ }^{a}$
84

16

$.1856^{\circ}$

41

0

55

5

96

4

$.0573^{\mathrm{c}}$

$.0714^{c}$
73

27

35

11

50

5

87

87
13

3

Teacher Experience

Average Number of Years of Experience

11.6

12.6

$>.9999^{\circ}$

${ }^{a}$ Chi-Square test of independence.

${ }^{b}$ t-test of equivalent means.

'Significance tests are adjusted for multiple comparisons using the Bonferroni method. 


\section{Appendix B. Comparison of Retained and Deleted Samples of Students on Eight Characteristics}

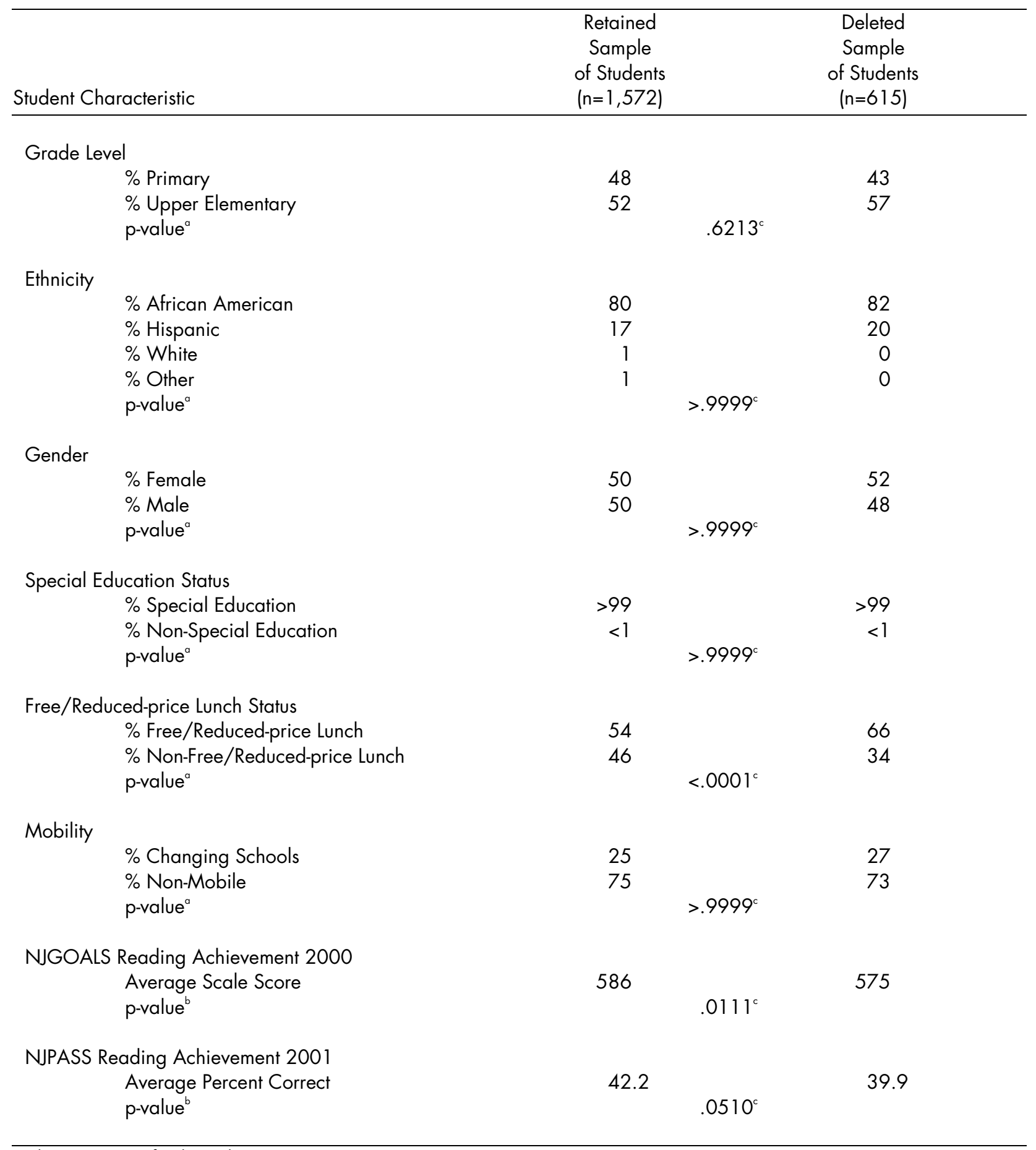

${ }^{a}$ Chi-Square test of independence.

${ }^{b}$ t-test of equivalent means.

'Significance tests are adjusted for multiple comparisons using the Bonferroni method. 


\section{Appendix C. Survey Scales}

Items on Writers Workshop Preparation Scale $(\alpha=.96)$

(based on a four-point scale ranging from "not adequately prepared" to "somewhat prepared" to "fairly well prepared" to "very well prepared")

How prepared do you feel to...

- Teach mini-lessons on the craft of writing.

- Teach mini-lessons on writing skills.

- Teach mini-lessons on classroom procedures.

- Hold writing conferences with students.

- Conduct narrative genre studies.

- Conduct informal genre studies.

- Conduct author studies.

- Identify and assist students with common writing problems.

- Conduct author's chair.

- Conduct writing conferences with small groups of students.

- Facilitate student writing response groups.

- Use elements of the standards to guide/revise your instruction.

- Teach students strategies for revising and editing their writing.

- Teach students to self-assess their own writing using the standards.

\section{Items on Readers Workshop Preparation Scale $(\alpha=\mathbf{. 9 4})$}

(based on a four-point scale ranging from "not adequately prepared" to "somewhat prepared" to "fairly well prepared" to "very well prepared")

How prepared do you feel to...

- Do guided reading with students.

- Have students read independently.

- Teach mini-lessons on phonics-based skills.

- Teach mini-lessons on comprehension skills (story maps, creating images, connections, summarizing, etc.).

- Teach mini-lessons on decoding skills and word analysis.

- Teach mini-lessons on classroom procedures (rituals and routines).

- Match students with leveled texts.

- Conduct reading conferences with small groups of students.

- Assess students using running records.

- Develop plans for student guided reading.

- Facilitate student book talks. 


\section{Appendix C. Survey Scales (continued)}

\section{Items on "Same Standards Should Apply to All Students" scale $(\alpha=.74)$}

(based on a four-point scale ranging from "strongly disagree" to "somewhat disagree" to "somewhat agree" to "strongly agree")

Indicate the extent to which you agree or disagree...

- Special Education students who are placed in regular classes should be expected to meet the same standards as other students.

- Limited English Proficient students who are placed in regular classes should be expected to meet the same standards as other students.

- I use the same criteria for all students to judge the quality of an assignment.

- Teachers should use the same standards in evaluating the work of all students in the class.

\section{Items on "All Students Can Learn" scale $(\alpha=.60)$}

(based on a four-point scale ranging from "strongly disagree" to "somewhat disagree" to "somewhat agree" to "strongly agree")

Indicate the extent to which you agree or disagree...

- The achievement of my students is primarily due to factors beyond my control. ${ }^{\circ}$

- If my students have adequate time, they can master the knowledge and skills expected of them.

- My students are not ready for problem solving until they have acquired the basics. ${ }^{\circ}$

- Many of the students I teach are not capable of learning the material I am supposed to teach them. ${ }^{\circ}$

- It is impractical for teachers to tailor instruction to the unique interests and abilities of individual students. ${ }^{\circ}$

- My students cannot work together without close supervision. ${ }^{\circ}$

- My students' success is based more on ability than effort. ${ }^{\circ}$

${ }^{a}$ Denotes reverse-coded items 


\section{Appendix D. Regression Coefficients from the Full Model (including control variables) Predicting Achievement Gains from Overall Implementation of America's Choice}

\begin{tabular}{llc}
\hline Predictor Variable & $\begin{array}{l}\text { Regression } \\
\text { Coefficient }\end{array}$ & Standard \\
Error
\end{tabular}

\section{Student Variables}

Prior Reading Achievement (2000 school year) $\quad .6587^{* * *}$

Prior Reading Achievement $\times$ ESPA

$.1530^{\sim}$

Current Grade Level (Primary Grades vs. Upper Elementary Grades) ${ }^{a}$

Student Gender (males vs. females)

Student Ethnicity (with African American as the reference category)

$$
\begin{array}{lc}
\text { Hispanic } & .1238^{*} \\
\text { Other Ethnicity } & .7823^{* *} \\
\text { White } & .1542 \\
\text { Student Eligible for Free or Reduced-price Lunch } & -.0781 \\
\text { Student Changed Schools from 2000 to 2001 } & -.2288^{* *}
\end{array}
$$

\section{Teacher Variables}

Teacher Gender (males vs. females)

Teacher Ethnicity (with African American as the reference category)

$$
\begin{array}{cr}
\text { White } & -.2273^{*} \\
\text { Other } & -.2710 \\
\text { Teacher Years of Experience }^{b} & -.0005
\end{array}
$$

\section{America's Choice Implementation ${ }^{a}$}

Overall Implementation (Primary Grades)

Overall Implementation (Upper Elementary Grades)

\section{Missing Data Indicator Variables}

Missing Student Gender

Missing Student Ethnicity

Missing Student Mobility

Missing Teacher Gender

Missing Teacher Ethnicity

${ }^{\circ}$ Estimates derived from an interaction of implementation and grade level in a single model.

${ }^{b}$ Effect of a one standard deviation increase. 


\section{Appendix E. Regression Coefficients from the Full Model (including control variables) Predicting Achievement Gains from Time Teaching Writers Workshop}

\begin{tabular}{llc}
\hline & Regression & Standard \\
Predictor Variable & Coefficient & Error \\
\hline
\end{tabular}

\section{Student Variables}

Prior Reading Achievement (2000 school year)

$$
\begin{aligned}
& .6660^{* * *} \\
& .1393^{\sim} \\
& .7737^{* *}
\end{aligned}
$$

Prior Reading Achievement $\times$ ESPA

Current Grade Level (Primary Grades vs. Upper Elementary Grades) ${ }^{a}$

Student Gender (males vs. females)

Student Ethnicity (with African American as the reference category)

Hispanic

$.1283^{*}$

Other Ethnicity

$.7805^{*}$

White

.1431

Student Eligible for Free or Reduced-price Lunch

Student Changed Schools from 2000 to 2001

$-.0983^{2}$

\section{Teacher Variables}

Teacher Gender (males vs. females)

$-.1722$

Teacher Ethnicity (with African American as the reference category)

$$
\begin{array}{cc}
\text { White } & -.2236^{*} \\
\text { Other } & -.0487 \\
\text { Teacher Years of Experience }^{b} & -.0006
\end{array}
$$

\section{America's Choice Implementation ${ }^{a}$}

Time Teaching Writers Workshop (Primary Grades)

Time Teaching Writers Workshop (Upper Elementary Grades)

\section{Missing Data Indicator Variables}

Missing Student Gender

Missing Student Ethnicity

Missing Student Mobility

Missing Teacher Gender

Missing Teacher Ethnicity

Missing Teacher Years of Experience

Missing Time Teaching Writers Workshop

$p<.10, p<.05, p<.01, p<.001$

${ }^{a}$ Estimates derived from an interaction of implementation and grade level in a single model.

${ }^{b}$ Effect of a one standard deviation increase. 


\section{Appendix F. Regression Coefficients from the Full Model (including control variables) Predicting Achievement Gains from Preparation to Teach Writers Workshop}

\begin{tabular}{llc}
\hline & Regression & Standard \\
Predictor Variable & Coefficient & Error \\
\hline
\end{tabular}

\section{Student Variables}

Prior Reading Achievement (2000 school year) $\quad .6537^{* * *}$

Prior Reading Achievement $\times$ ESPA

$.1638^{*}$

Current Grade Level (Primary Grades vs. Upper Elementary Grades) ${ }^{a}$

Student Gender (males vs. females)

Student Ethnicity (with African American as the reference category)

Hispanic

$.1263^{*}$

Other Ethnicity

$.7802^{* *}$

White

.1506

Student Eligible for Free or Reduced-price Lunch

$-.0846$

Student Changed Schools from 2000 to 2001

$-.2286^{* \prime}$

\section{Teacher Variables}

Teacher Gender (males vs. females)

$-.1840$

Teacher Ethnicity (with African American as the reference category)

White

$-.2311^{*}$

Other

Teacher Years of Experience ${ }^{b}$

.0002

\section{America's Choice Implementation $^{a}$}

Preparation to Teach Writers Workshop (Primary Grades)

Preparation to Teach Writers Workshop (Upper Elementary Grades)

\section{Missing Data Indicator Variables}

Missing Student Gender

Missing Student Ethnicity

$-.4539$

Missing Student Mobility

Missing Teacher Gender

Missing Teacher Ethnicity

Missing Teacher Years of Experience

Missing Preparation to Teach Writers Workshop

i $p<.10,{ }^{*} p<.05,{ }^{* *} p<.01,{ }^{* * *} p<.001$

a Estimates derived from an interaction of implementation and grade level in a single model.

${ }^{b}$ Effect of a one standard deviation increase. 


\section{Appendix G. Regression Coefficients from the Full Model (including control variables) Predicting Achievement Gains from Time Teaching Readers Workshop}

\begin{tabular}{llc}
\hline Predictor Variable & $\begin{array}{c}\text { Regression } \\
\text { Coefficient }\end{array}$ & $\begin{array}{c}\text { Standard } \\
\text { Error }\end{array}$ \\
\hline
\end{tabular}

\section{Student Variables}

Prior Reading Achievement (2000 school year)

$$
\begin{aligned}
& .6653^{\star \star \star} \\
& .1467^{\sim} \\
& .8712^{\star \star \star} \\
& -.2315^{\star \star \star}
\end{aligned}
$$

Prior Reading Achievement $\times$ ESPA

Current Grade Level (Primary Grades vs. Upper Elementary Grades) ${ }^{a} \quad .8712^{* * *}$

Student Gender (males vs. females)

Student Ethnicity (with African American as the reference category)

$$
\begin{array}{lc}
\text { Hispanic } & .1220^{*} \\
\text { Other Ethnicity } & .7837^{* *} \\
\text { White } & .1501 \\
\text { Student Eligible for Free or Reduced-price Lunch } & -.0898^{\sim} \\
\text { Student Changed Schools from 2000 to 2001 } & -.2010^{* *}
\end{array}
$$

\section{Teacher Variables}

Teacher Gender (males vs. females)

Teacher Ethnicity (with African American as the reference category)

$$
\begin{array}{cr}
\text { White } & -.2424^{*} \\
\text { Other } & -.1680 \\
\text { Teacher Years of Experience }^{b} & .0003
\end{array}
$$

\begin{tabular}{|c|c|}
\hline Missing Student Gender & -.4229 \\
\hline Missing Student Ethnicity & .2885 \\
\hline Missing Student Mobility & .1028 \\
\hline Missing Teacher Gender & .0702 \\
\hline Missing Teacher Ethnicity & -.2823 \\
\hline Missing Teacher Years of Experience & -.2644 \\
\hline Missing Time Teaching Readers Workshop & -.3085 \\
\hline
\end{tabular}

\section{America's Choice Implementation ${ }^{\circ}$}

Time Teaching Readers Workshop (Primary Grades)

Time Teaching Readers Workshop (Upper Elementary Grades)

\section{Missing Data Indicator Variables}




\section{Appendix H. Regression Coefficients from the Full Model (including control variables) Predicting Achievement Gains from Preparation to Teach Readers Workshop}

\begin{tabular}{llc}
\hline & Regression & Standard \\
Predictor Variable & Coefficient & Error \\
\hline
\end{tabular}

\section{Student Variables}

Prior Reading Achievement (2000 school year) $\quad .6558^{* * *}$

Prior Reading Achievement $\times$ ESPA

$.1594^{\sim}$

Current Grade Level (Primary Grades vs. Upper Elementary Grades) ${ }^{a}$

Student Gender (males vs. females)

$.8089^{* * *}$

Student Ethnicity (with African American as the reference category)

$-.2319^{* * *}$

Hispanic

$.1244^{*}$

Other Ethnicity

$.7765^{* *}$

White

.1613

Student Eligible for Free or Reduced-price Lunch

$-.0817$

Student Changed Schools from 2000 to 2001

$-.2285^{*}$

\section{Teacher Variables}

Teacher Gender (males vs. females)

$-.2006$

Teacher Ethnicity (with African American as the reference category)

White

$-.1970$

Other

$-.2539$

Teacher Years of Experience ${ }^{b}$

.0015

\section{America's Choice Implementation $^{\circ}$}

Preparation to Teach Readers Workshop (Primary Grades)

.0811

Preparation to Teach Readers Workshop (Upper Elementary Grades)

\section{Missing Data Indicator Variables}

Missing Student Gender

Missing Student Ethnicity

Missing Student Mobility

Missing Teacher Gender

$-.0636$

Missing Teacher Ethnicity

$-.2066$

Missing Teacher Years of Experience

$-.1451$

Missing Preparation to Teach Readers Workshop

.2132

$\tilde{} p<.10,{ }^{*} p<.05,{ }^{* *} p<.01,{ }^{\star \star *} p<.001$

${ }^{a}$ Estimates derived from an interaction of implementation and grade level in a single model.

${ }^{b}$ Effect of a one standard deviation increase. 


\begin{tabular}{llc}
$\begin{array}{l}\text { Appendix I. Regression Coefficients from the Full Model (including control variables) } \\
\text { Predicting Achievement Gains from "All Students Can Learn" }\end{array}$ \\
\hline Predictor Variable & $\begin{array}{c}\text { Regression } \\
\text { Coefficient }\end{array}$ & $\begin{array}{c}\text { Standard } \\
\text { Error }\end{array}$ \\
\hline
\end{tabular}

\section{Student Variables}

Prior Reading Achievement (2000 school year) $\quad .6529^{* * *}$

Prior Reading Achievement $\times$ ESPA

$.1632^{\sim}$

Current Grade Level (Primary Grades vs. Upper Elementary Grades) ${ }^{\circ}$

$.7528^{* * *}$

Student Gender (males vs. females)

$-.2338^{* * *}$

Student Ethnicity (with African American as the reference category)

Hispanic

$.1264^{*}$

Other Ethnicity

$.7855^{* *}$

White

.1464

Student Eligible for Free or Reduced-price Lunch

$-.0754$

Student Changed Schools from 2000 to 2001

$-.2398^{*}$

\section{Teacher Variables}

Teacher Gender (males vs. females)

Teacher Ethnicity (with African American as the reference category)

$\begin{array}{ll}\text { White } & -.2445^{*} \\ \text { Other } & -.3666 \\ & .0006\end{array}$

Teacher Years of Experience ${ }^{b}$

\section{America's Choice Implementation ${ }^{a}$}

"All Students Can Learn" (Primary Grades) $\quad 0365$

"All Students Can Learn" (Upper Elementary Grades)

\section{Missing Data Indicator Variables}

\begin{tabular}{|c|c|}
\hline Missing Student Gender & -.4193 \\
\hline Missing Student Ethnicity & .2920 \\
\hline Missing Student Mobility & .0812 \\
\hline Missing Teacher Gender & -.0675 \\
\hline Missing Teacher Ethnicity & -.2868 \\
\hline Missing Teacher Years of Experience & -.1879 \\
\hline Missing "All Students Can Learn" & .2754 \\
\hline
\end{tabular}




\section{Appendix J. Regression Coefficients from the Full Model (including control variables) Predicting Achievement Gains from "Same Standards Should Apply to All Students"}

\begin{tabular}{llc}
\hline Predictor Variable & $\begin{array}{l}\text { Regression } \\
\text { Coefficient }\end{array}$ & $\begin{array}{c}\text { Standard } \\
\text { Error }\end{array}$ \\
\hline
\end{tabular}

\section{Student Variables}

Prior Reading Achievement (2000 school year) $\quad .6582^{* * *}$

Prior Reading Achievement $\times$ ESPA

Current Grade Level (Primary Grades vs. Upper Elementary Grades) ${ }^{a}$

Student Gender (males vs. females)

Student Ethnicity (with African American as the reference category)

$$
\begin{aligned}
& \text { Hispanic } \\
& \text { Other Ethnicity }
\end{aligned}
$$

White

Student Eligible for Free or Reduced-price Lunch

Student Changed Schools from 2000 to 2001

\section{Teacher Variables}

Teacher Gender (males vs. females)

$-.1904$

Teacher Ethnicity (with African American as the reference category)

$$
\text { White }
$$

Other

Teacher Years of Experience ${ }^{b}$

$.1233^{*}$

$.7973^{* *}$

.1557

$-.0747$

$-.2434^{* *+}$

\section{America's Choice Implementation ${ }^{\circ}$}

"Same Standards Should Apply to All Students" (Primary Grades)

"Same Standards Should Apply to All Students" (Upper Elementary Grades)

.0320

\section{Missing Data Indicator Variables}

Missing Student Gender

Missing Student Ethnicity

Missing Student Mobility

Missing Teacher Gender

$-.0463$

Missing Teacher Ethnicity

Missing Teacher Years of Experience

${ }^{a}$ Estimates derived from an interaction of implementation and grade level in a single model.

${ }^{b}$ Effect of a one standard deviation increase. 